\title{
EFFECTS OF DIFFERENT HUMIC ACID AND SALINITY LEVELS ON SOME TRAITS OF KHUZESTANI SAVORY (SATUREJA KHUZISTANICA JAMZAD)
}

\author{
ZAREMANESH, H. ${ }^{1}$ - EISVAND, H. R. $.^{1 *}-$ AKBARI, N $.^{1}-$ ISMAILI, A. ${ }^{1}-$ FEIZIAN, M. ${ }^{2}$ \\ ${ }^{I}$ Department of Agronomy and Plant Breeding, Faculty of Agriculture, Lorestan University, \\ Khorramabad, Iran \\ ${ }^{2}$ Department of Soil Science, Faculty of Agriculture, Lorestan University, Khorramabad, Iran \\ *Corresponding author \\ e-mail: eisvand.hr@lu.ac.ir
}

(Received $29^{\text {th }}$ Nov 2018; accepted $28^{\text {th }}$ Feb 2019)

\begin{abstract}
In order to study the impact of humic acid on some morphological, physiological and biochemical traits of Khuzestani savory under salinity stress condition, the present study was conducted in the greenhouse of the agricultural faculty of Lorestan University as a factorial experiment (combination of humic acid and salinity) in the form of randomized complete blocks design (RCBD) in 2017. Factors of the experiment included salinity in five levels $(0,25,50,75$ and $100 \mathrm{mM}$ of $\mathrm{NaCl})$ and humic acid also in five levels $(0,10,20,30$ and $40 \mathrm{mg} / \mathrm{Kg}$ of soil), which were applied as a pot experiment. Results revealed that in terms of morphological traits including stem length, root length, leaf length, leaf width and leaf area, the highest salinity (S5) and "without humic acid" (H1) (S5H1) produced the lowest values; whereas "without salinity" (S1) and highest humic acid (H5) (S1H5) produced the highest values for these traits. Moreover, $\mathrm{S} 1 \mathrm{H} 5$ treatment produced the highest photosynthesis and transpiration rates of $24.04 \mu \mathrm{mol} \mathrm{CO} \mathrm{Cm}^{-2} \mathrm{~s}^{-1}$ and $2.85 \mathrm{mmol} \mathrm{H}_{2} \mathrm{O}_{2} \mathrm{~m}^{-2} \mathrm{~s}^{-1}$, respectively; whereas, lowest values for the traits were produced in $\mathrm{S} 5 \mathrm{H} 1$ treatment to be $5.67 \mu \mathrm{mol} \mathrm{CO}_{2} \mathrm{~m}^{-2} \mathrm{~s}^{-1}$ and $0.65 \mathrm{mmol} \mathrm{H}_{2} \mathrm{O}_{2} \mathrm{~m}^{-2} \mathrm{~s}^{-1}$, respectively. Furthermore, $\mathrm{S} 1 \mathrm{H} 5$ treatment produced the highest $\left(0.280 \mathrm{~mol} \mathrm{CO}_{2} \mathrm{~m}^{-2} \mathrm{~s}^{-1}\right)$ stomatal conductance rate and lowest substomatal $\mathrm{CO}_{2}(85 \mathrm{ppm})$; whereas, $\mathrm{S} 5 \mathrm{H} 1$ treatment produced the lowest $\left(0.013 \mathrm{~mol} \mathrm{CO}_{2} \mathrm{~m}^{-2} \mathrm{~s}^{-1}\right)$ stomatal conductance rate and highest $(406 \mathrm{ppm})$ substomatal $\mathrm{CO}_{2}$. The highest organic matter content (89.69\% on average) was found in $\mathrm{S} 2 \mathrm{H} 3$ treatment, whereas it reached to its lowest value $(69.46 \%$ overage) in $\mathrm{S} 4 \mathrm{H} 5$ treatment. Moreover, $\mathrm{S} 5 \mathrm{H} 2$ treatment produced the highest (24.37\% on average) and S1H5 treatment the lowest (10.35\% on average) ash percentage trait. As for relative water content (RWC) of leaf, the highest (93.01\% on average) and lowest (70.94\%) values were produced in S1H5 and S5H1 treatments, respectively. S5H1 had the highest $(0.334 \mathrm{mg} / \mathrm{g}$ of fresh weight) proline content and $\mathrm{S} 5 \mathrm{H} 5$ had the highest $(2.098 \mathrm{mg} / \mathrm{g}$ of dry matter) soluble sugar content; whereas, the lowest proline content $(0.155 \mathrm{mg} / \mathrm{g}$ of fresh weight $)$ and soluble sugar content $(0.808 \mathrm{mg} / \mathrm{g}$ of dry matter $)$ were produced in S1H5 and S1H1 (control) treatments, respectively.
\end{abstract}

Keywords: salt stress, organic fertilizer, morphology, physiology, biochemistry

\section{Introduction}

Plant growth and its resulting yield are influenced by numerous environmental factors. Worldwide, normal plant growth is challenged by a great number of environmental factors particularly drought, salinity, nutrient imbalance, toxicity and critical temperatures (Ashraf, 1994). Although, secondary plant metabolites are characterized by their importance in plant tolerance against environmental stresses, mechanism of their response to the environmental stresses keeps boggling the minds. Although, there is numerous evidence that the environmental stresses have an increasing effect on the secondary metabolites content of plants; this effect is limited and in some cases even happens in reverse. Furthermore, quality of these substances is 
influenced by the environmental stresses as well. It is known that plant species mainly use the mechanism of growth reduction and change in constituents of the secondary metabolites to survive in the environmental stresses. Environmental stresses, both biotic and abiotic, are serious and unforgiving threats for the crops. Drought, salinity, extreme cold and warm temperatures are the most notable abiotic stresses that reduce yield and increase economical costs at the global level (Nakabayashi and Saito, 2015).

One of the globally most infamous environmental factors is salinity, which is known for its negative impact on growth and yield of plants all over the world (Sevengor et al., 2011; Amirjani et al., 2010; Zhani et al., 2012). More specifically, impacts of salinity stress on the plants include ionic toxicity, osmotic stress, mineral deficiency, physiological and biochemical disorders and a combination of them (Saleh, 2013; Rajaravindran, 2012).

Curiously, salinity inhibits plant growth mainly through decreasing water potential in root zone, salinity-induced accumulation of ions and compromised nourishment balance; which finally lead to physiological, morphological as well as metabolic changes (Parvin et al., 2012). Interestingly, the most important monitoring parameters of effects of environmental stresses, particularly salinity and drought stresses are stem length and root length. This is because roots are in direct contact with the soil and the water and nutrients it absorbs from the soil are transported by the stem to other parts of the plant; thus, changes in the lengths of stem and root can best represent the response of plants to the salinity stress (Jamil, 2005).

Although limited plant growth under salinity stress may not simply be attributed to a change in the specific physiological processes, photosynthesis is known to be the dominant physiological process limiting plant growth (Sudhir and Murthy, 2004). Salinity reduces plant growth and yield by compromising its physiological processes particularly photosynthesis; while intensity of the effect depends on the degree and duration of the salinity stress (Chaves et al., 2009). Reports suggest that lower water potential of leaf causes the stomata to close, compromises $\mathrm{CO}_{2}$ supply of the plant and finally decreases the rate of photosynthesis. Closing of the stomata is probably the first line of defense against the loss of water and the most important factor affecting the rate of carbon fixation (Da Silva et al., 2008).

Furthermore, salinity stress decreases osmotic potential that leads to decreased water absorption followed by decreased transpiration, which if continued long enough can cause plants to die (Sivritepe et al., 2010). Moreover, proline accumulation is one of the key physiological parameters used to assess plant tolerance and plays an important part in its adaptation to stress. Generally, proline accumulation occurs in plants that are exposed to extreme conditions of drought and salinity. Probably, proline synthesis in a plant is the result of its nonspecific response to low water potential. Moreover, proline may play a part in osmoregulation and maintaining the enzymatic activity of plants. In addition to the part it plays in osmotic modification, this amino acid contributes to fixation of cellular parts, absorption of free radicals, buffering state of cell oxidation potential, and other various processes against stresses (Ashraf and Foolad, 2007).

Under salinity stress, the insoluble sugars (starch) are broken down to soluble ones and this enables the cell to maintain osmotic potential and avoid dehydration. In addition, decreased sugar consumption due to decreased photosynthesis during the salinity stress causes further increase in the intracellular concentration of soluble sugars (Parvaiz and Satyawati, 2008). The salinity induced damages to plants occur through osmotic effect, ion toxicity, and compromised nutrient absorption. Humic acid is a 
constituent of humus and is dark brown in color. As a compound it contains sulfur, nitrogen, phosphorus in various percentages and some of the metals such as calcium, magnesium, copper, zinc etc. Soil salinity can be reduced by using new methods such as application of microorganisms, humic acid and folic acid, algae and herbal extracts to the soil (Bashan et al., 2014; Calvo et al., 2014).

Biochemically, humic acid is the active ingredient of humus (Nasouti Miandoab et al., 2011). Humic acid can have direct and positive impacts on plant growth by stimulating the growth of both shoot and root systems. Its impact on root is more predominant, while it can increase root volume which in turn improves efficiency of the root system. Humic acid can also increase the uptake of nitrogen, potassium, calcium, magnesium and phosphorus by the plant (Soltani, 2002). Possibly, humic acid contributes the growth traits through interaction with mineral ions, conversion to enzymes found in the plant, improving transpiration and photosynthesis and triggering hormonal activities (El-Sherbeny et al., 2012).

Owing to its characteristic composition, humic acid is capable of reducing the salt content of soil and negating its effect. Presence of humic acid in the soil can improve photosynthesis as well as tolerance against the biotic and abiotic stresses including diseases. Moreover, it boosts plant defense system by adding natural antioxidants and phenolic acid. Humic acid delays chlorosis through improving the uptake of magnesium and iron (Nasouti Miandoab et al., 2011).

Based on the above discussion and the increasing interest on medicinal plants, particularly in the technologically advanced communities, the importance of their preservation and propagation by using new cost-effective methods and create jobs and sustainable income can never be overemphasized. Khuzestani savory is one of the important medicinal plants in Iranian as well as global traditional medicine (Fig. 1). Khuzestani savory (Satureja khuzistanica Jamzad) is an aromatic perennial plant exclusively native to climatically arid southeastern region of Iran where it grows in limy-stony soils (Hadian et al., 2010). Geographical distribution of Khuzestani savory (Fig. 2) is in between Andimeshk and Pol Dokhtar towns in Palan village, Lorestan Province; and $72 \mathrm{~km}$ far from Andimeshk towards Khorramabad and $5 \mathrm{~km}$ after Tang Bridge on the clefts of limestone rocks in Sahara-Sindhi area at 474-520 m elevation (Jamzad, 2009). Savory belongs to Lamiaceae family and is among the species with remarkable antioxidant properties. For a long time, savory is being used as condiment and flavoring ingredient in canned food, soft drinks and manufacturing a variety of meat products and sausages. The essential oil content of above ground parts of savory varies in terms of the climatic condition under which the plant has grown and ranges between 1 and $2 \%$. The most important compounds found in the essential oil of the plant include carvacrol (24.5\%), thymol (23.12\%), Gamma Terpinene (20.72\%) and p-cymene $(6.30 \%)$ (Kamkar et al., 2013).

More than 800 million hectares of the land area in the world, accounting for six percent of the total, is affected by salinity (Seckin et al., 2010). Salinity is a pervasive problem in Iran and limits sustainable agricultural production. Large parts of the arid and semi-arid regions in the country (especially in the Central Iranian Plateau, the southern coastal plains and the Khuzestan Plain) suffer from salinity (FAO, 1972; Naghizadeh et al., 2014).

Since wild Khuzestani savory (Satureja khuzestanica) grows in stony calcareous areas, this research was conducted to determine to what extent it could tolerate salinity and to prepare the ground for planting it on saline soils. Soil salinity plays a deciding 
role in plant growth and development. Most plants are sensitive to salinity, but a small group of them can somewhat tolerate soil salinity. The quantity of active ingredients in medicinal plants is influenced by soil salinity. Therefore, determination of soil salinity level has an effective role in production of medicinal plants. Naturally, yield of Khuzestani savory also decreases under the harmful influence of salinity.

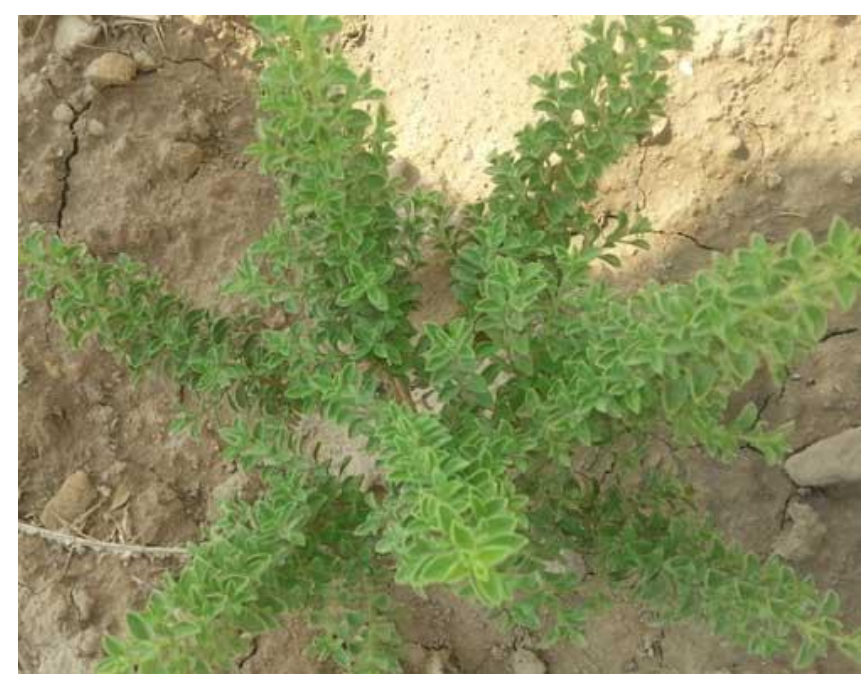

Figure 1. Satureja khuzistanica

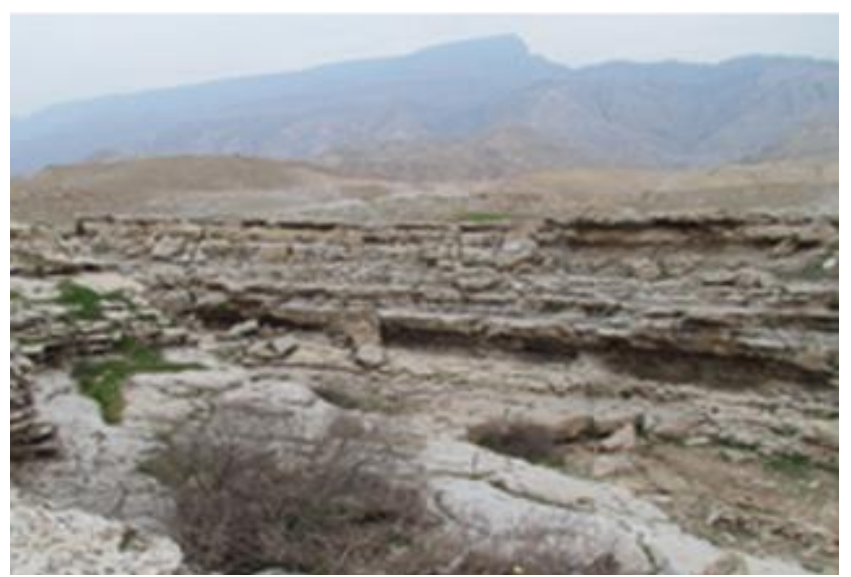

Figure 2. Satureja khuzestanica habitat in Lorestan Province (Mohebbi et al., 2016)

This plant is wild-growing and found in sunny, stony, and calcareous areas of Lorestan and Khuzestan Provinces of Iran. Its cultivation is not common at present and most studies on it were conducted in greenhouses. Therefore, it is harvested in nature for medicinal purposes, which can be accompanied by the risk of its extinction. Nowadays, Satureja hortensis is widely planted. A summary of the method of cultivation this crop is as follows:

Like other annual plants, Khuzestani savory can be planted in rotation with most other crops. The desirable temperature for seed germination is $20-22{ }^{\circ} \mathrm{C}$. Since this plant is sensitive to cold, the most suitable time for planting it is spring (from late April to late May). Seeds are planted in rows in the field in spring. Row spacing differs 
depending on the planting method. In small-scale planting by hand, the suitable row spacing is $25-30 \mathrm{~cm}$. If seeds are machine-planted, the $45-50 \mathrm{~cm}$ row spacing will be more appropriate. The suitable number of seeds is $120-140$ per meter of row. Planting depth in different soils varies from 0.5 to $1.5 \mathrm{~cm}$. $4-8 \mathrm{~kg}$ of seeds is required per hectare. It is recommended that the land is properly rolled after planting. This operation results in compaction of the surface soil layer and favorably influences uniform seed germination. The field must be irrigated after planting.

If planting density is high, thinning is carried out. The 4-6 leaf stage is suitable for this operation. Weed control is necessary during the growing season. Inter-row weed control by using a cultivator, especially after the first harvest, plays a major role in increasing yield. Plants have their highest essential oil content during the flowering stage. Therefore, harvesting the vegetative part is done at this stage. If plants are suitably looked after with respect to irrigation, soil, and contents of nutrients in soil that are necessary for satisfactory plant growth, it will be possible to harvest the crop 2 or even 3 times per year. The first harvest is carried out at the start of the flowering stage and the second in late September. All aerial organs of the plants are harvested by machine or manually using a scythe. Fruit usually matures 140-160 days after seed germination. Late August, when seeds gradually turn brown, is the suitable time for collecting seeds. Delays in collecting seeds should be avoided as completely mature seeds are scattered by the faintest blows inflicted on the plants.

The present study focused on effect of humic acid on some of the morphological, physiological and biochemical traits of the medicinal plant Khuzestani savory (Satureja khuzistanica Jamzad) under salinity stress. Hopefully, results from this study can pave the way for prospective studies in the field and help to promote cultivation of the medicinal plants.

\section{Materials and methods}

The present study was conducted as a greenhouse experiment in 2017 at Lorestan University, Iran. The experiment was conducted as factorial based on a randomized complete block design (RCBD) with four replications. The first factor included humic acid in five levels (zero, 10, 20, 30 and $40 \mathrm{mg} / \mathrm{Kg}$ soil) that was applied before planting. The second factor was salinity stress in five levels (zero, 25, 50, 75 and $100 \mathrm{mM} \mathrm{NaCl}$ ) which was applied after sprouting and establishment of the plants during the fourth leaf stage. Levels of the factors being studied are shown in Table 1.

The humic acid was applied to the soil in the pots before the plantation of seeds. Pots used in the experiment were plastic pots made of polyethylene, each $280 \mathrm{~g}$ in weight $15.5 \mathrm{~cm}$ in diameter and $18 \mathrm{~cm}$ in height. Volume of each pot was $4 \mathrm{Kg}$ and they were filled with soil-gravel-sheep manure in 2:1:0.5 ratio. Prior to plantation, savory seeds (Satureja Khuzistanica Jamzad) were disinfected by sodium hypochlorite $10 \%$ solution for $3 \mathrm{~min}$ and as many as 15 seeds were planted in each pot at a depth of $1-2 \mathrm{~cm}$. After sprouting and during the fourth leaf stage the planting density was thinned to 8 plants. Cultivation included weeding, irrigation and application of salinity after fourth leaf stage to the treatments.

In order to study the morphological parameters, 5 plants were selected randomly from each experimental unit and average values were calculated in $\mathrm{mm}$ for traits such as stem length, root length, leaf length and leaf width by using a ruler. 
Finally, analysis of variance of data was done using SAS9.4 software. Also, for posthoc analysis, the comparing the means of combination of treatment was done using Duncan's multiple range test at 5\% probability level.

Table 1. Different levels of salinity and humic acid applied in the experiment

\begin{tabular}{c|c|c|c}
\hline \multicolumn{2}{c|}{ Humic acid (mg/kg soil) } & \multicolumn{2}{c}{ Salinity (NaCl mM) } \\
\hline Level of treatment & Abbreviation & Level of treatment & Abbreviation \\
\hline 0 & H1 & 0 & S1 \\
10 & H2 & 25 & S2 \\
20 & H3 & 50 & S3 \\
30 & H4 & 75 & S4 \\
40 & H5 & 100 & S5 \\
\hline
\end{tabular}

\section{Leaf relative water content $(R W C)$}

In order to measure the RWC of leaf, samples were taken from the reference leaf (last developed leaf) in the experimental units and immediately put into ice; then their wet weight was measured (in 0.0001 accuracy) in the lab. The samples were put into distilled water and kept in Cold Room under $4{ }^{\circ} \mathrm{C}$ for $24 \mathrm{~h}$. Then, saturated weight of the leafs was measured before putting them in an oven under $70^{\circ} \mathrm{C}$ for another $24 \mathrm{~h}$ and measuring their dry weight. The obtained values and the following equation were used to calculate the RWC (Ritchie et al., 1990):

$$
\mathrm{RWC}=(\mathrm{Fw}-\mathrm{Dw} / \mathrm{Sw}-\mathrm{Dw}) \times 100
$$

where Fw is the wet weight of leaf immediately after sampling, Dw is the dry weight of leaf after taken out of oven, $\mathrm{Sw}$ is the saturated weight of leaf after removed from distilled water.

\section{Measurement of leaf area}

Leaf area were obtained using the leaf area measuring instrument (LI-3000A, USA) by putting leafs on the instrument.

\section{Measurement of soluble sugars}

Firstly, the sample leafs were dried out by putting into the oven under $110^{\circ} \mathrm{C}$ for $48 \mathrm{~h}$ and digital scale was used to take $0.1 \mathrm{~g}$ of each sample. Then, as much as $10 \mathrm{~mL}$ $70 \%$ alcohol was added to each sample in polyethylene containers and kept in refrigerator for one week. During this process, the soluble sugars were solved in ethanol and accumulated at the top layer, from which $1 \mathrm{~mL}$ was taken and added to a mixture containing $1 \mathrm{~mL} \mathrm{5 \%}$ phenol and $5 \mathrm{~mL}$ concentrated sulfuric acid. The obtained solution was initially yellow in color, which changed over time. The solution was kept in the ambient temperature of laboratory to cool down for half an hour to obtain its final color. Finally, optical absorbance of the solution in $485 \mathrm{~nm}$ was obtained by using spectrophotometer. In order to calculate the density of soluble sugars for the samples (C), solutions with glucose $0,10,20,50,100,200$ and $300 \mathrm{mg} / \mathrm{L}$ were prepared as control sugar by using the standard curve and all the procedures were repeated on $2 \mathrm{~mL}$ 
of each solution. Sugar value was obtained for the plant samples in $\mathrm{mg} / \mathrm{g}$ (Kochert, 1978).

\section{Extraction and measurement of proline}

In the present study proline content was measured by using method of Bates et al. (1973). The measurement process involved pulverizing $0.5 \mathrm{~g}$ of wet plant material inside a porcelain mortar while gradually adding $10 \mathrm{~mL} 3 \%$ sulfosalicylic acid. Then, the obtained solution was centrifuged inside a test tube at $3000 \mathrm{round} / \mathrm{min}$ for $15 \mathrm{~min}$ to become homogenous. The solution was filtered and $2 \mathrm{~mL}$ of it was taken and after adding $2 \mathrm{~mL}$ ninhydrin as reagent and $2 \mathrm{~mL}$ pure acetic acid was put in bain-marie under $100{ }^{\circ} \mathrm{C}$ for 1 hour before being put into ice bath. After adding $4 \mathrm{~mL}$ toluene in each tube, two phases were formed. The upper phase containing colored complex, was used to measure the proline content. Absorbance of the upper phase was read at $520 \mathrm{~nm}$ wavelength by using spectrophotometer, while proline content was obtained by using the standard diagram.

\section{Measurement of ash and organic matter}

As much as $1 \mathrm{~g}$ of dried shoot and leaf of the savory was pulverized using a mortar and weighed in porcelain containers. Then, the samples were burned on the heater for $2 \mathrm{~h}$ and put into an oven under $550{ }^{\circ} \mathrm{C}$ for $6 \mathrm{~h}$. The residual grey colored matter in the container was ash. The porcelain containers were reweighed in order to obtain the ash percentage. Following equation was used to determine the ash percentage (AOAC, 1990).

$$
\mathrm{Ash} \%=(\mathrm{M} 3-\mathrm{M} 2 / \mathrm{M} 1) \times 100
$$

where $\mathrm{M}_{3}$ was weight of porcelain container containing ash; $\mathrm{M}_{2}$ was weight of porcelain container; and $\mathrm{M}_{1}$ was weight of sample.

Furthermore, organic matter was measured using the following equation:

$$
\text { Organic matter percentage }=100-\text { ash percentage }
$$

\section{Measurement of photosynthesis, transpiration, stomatal conductance and substomatal $\mathrm{CO}_{2}$ concentration}

Traits associated with gas exchanges were measured based on method developed by Sudhakar et al. (2016). Gas exchange analyzer (LCA4, ADC, England) was used to measure stomatal conductance $\left(\mathrm{molCO}_{2} \cdot \mathrm{m}^{-2} \cdot \mathrm{s}^{-1}\right)$, transpiration rate $\left(\mathrm{mmol} \mathrm{H} \mathrm{H}_{2} \mathrm{O} \cdot \mathrm{m}^{-2} \cdot \mathrm{s}^{-1}\right)$, photosynthesis rate $\left(\mu \mathrm{molCO} 2 \cdot \mathrm{m}^{-2} \cdot \mathrm{s}^{-1}\right)$ and substomatal $\mathrm{CO}_{2}$ concentration $(\mathrm{ppm})$. All the measurements and note-takings concerning gas exchange values were carried out during morning hours (almost 8-10 PM).

\section{Results}

\section{Length of stem and root}

ANOVA results on the stem and root length traits (Table 2) and results obtained from comparing the means of interactive effects (Table 3) indicated that the S1H5 
treatment composition produced the longest stems $(28.4 \mathrm{~cm})$ although there were no significant differences between them and those of the treatment composition S2H5. The shortest stems $(14.5 \mathrm{~cm})$ belonged to the treatment composition $\mathrm{S} 5 \mathrm{H} 1$, but there were no significant differences between them and those of the treatment composition S5H2.

Table 2. Analysis of variance (mean squares) on morphological traits of Khuzestani savory under effects of salinity and humic acid

\begin{tabular}{c|c|c|c|c|c|c}
\hline & df & Leaf area & Leaf width & Leaf length & Root length & Stem length \\
\hline Rep & 3 & 32.49 & 1.92 & 0.79 & 5.08 & 5.92 \\
Salinity (S) & 4 & $291.5^{* *}$ & $4.85^{* *}$ & $1.80^{* *}$ & $16.02^{* *}$ & $274^{* *}$ \\
Humic acid (H) & 4 & $486^{* *}$ & $4.26^{* *}$ & $3.81^{* *}$ & $30.25^{* *}$ & $83.4^{* *}$ \\
S $\times$ H & 16 & $1^{\text {ns }}$ & $0.0098^{\text {ns }}$ & $0.0054^{\text {ns }}$ & $0.035^{\text {ns }}$ & $0.61^{\text {ns }}$ \\
Error & 72 & 7.82 & 0.19 & 0.13 & 1.26 & 0.97 \\
CV\% & & 3.96 & 13.64 & 11.41 & 7.10 & 4.62 \\
\hline
\end{tabular}

$\mathrm{ns}, *$ and $* *$ stand for non-significant, significant at 5 and $1 \%$ probability levels, respectively

Table 3. Mean comparison on interaction effects of salinity levels and humic acid on morphological traits of Khuzestani savory

\begin{tabular}{|c|c|c|c|c|c|c|c|c|c|c|}
\hline \multirow[b]{2}{*}{ S1H1 } & \multicolumn{2}{|c|}{$\begin{array}{l}\text { Leaf area } \\
\left(\mathrm{mm}^{2}\right)\end{array}$} & \multicolumn{2}{|c|}{$\begin{array}{l}\text { Leaf width } \\
\text { (mm) }\end{array}$} & \multicolumn{2}{|c|}{$\begin{array}{l}\text { Leaf length } \\
\text { (cm) }\end{array}$} & \multicolumn{2}{|c|}{$\begin{array}{l}\text { Root length } \\
\text { (cm) }\end{array}$} & \multicolumn{2}{|c|}{$\begin{array}{l}\text { Stem length } \\
\text { (cm) }\end{array}$} \\
\hline & 69.5 & fgh & 3.34 & defg & 3.04 & efghi & 15.5 & efghi & 22.3 & $\mathrm{gh}$ \\
\hline S1H2 & 71.5 & ef & 3.54 & cdef & 3.24 & cdefgh & 16.3 & cdefg & 23.7 & ef \\
\hline S1H3 & 74.5 & cde & 4.07 & $a b c$ & 3.57 & bcd & 17.2 & abcd & 25.1 & $\mathrm{~cd}$ \\
\hline S1H4 & 78.5 & $\mathrm{ab}$ & 4.36 & $a b$ & 3.73 & $a b c$ & 17.9 & $a b$ & 26.5 & $\mathrm{bc}$ \\
\hline S1H5 & 81.5 & $\mathrm{a}$ & 4.64 & $\mathrm{a}$ & 4.17 & $\mathrm{a}$ & 18.5 & $\mathrm{a}$ & 28.4 & $\mathrm{a}$ \\
\hline S2H1 & 67.5 & ghi & 2.78 & hijk & 2.79 & ghijk & 14.7 & hijk & 21.6 & hi \\
\hline $\mathrm{S} 2 \mathrm{H} 2$ & 69.5 & fgh & 2.98 & fghij & 2.99 & efghij & 15.5 & efghi & 22.7 & fgh \\
\hline S2H3 & 72.5 & def & 3.31 & defg & 3.32 & cdef & 16.5 & bcdef & 24.2 & de \\
\hline S2H4 & 76.5 & $\mathrm{bc}$ & 3.62 & cde & 3.63 & bcd & 17.2 & $a b c d$ & 26.2 & $\mathrm{c}$ \\
\hline S2H5 & 80.5 & $\mathrm{a}$ & 3.85 & bcd & 3.86 & $a b$ & 17.8 & $a b c$ & 27.7 & $a b$ \\
\hline S3H1 & 65 & $\mathrm{ijk}$ & 2.58 & ijkl & 2.65 & $\mathrm{ijkl}$ & 14.05 & ijkl & 19.6 & $\mathrm{jk}$ \\
\hline S3H2 & 67 & hi & 2.78 & ghijk & 2.85 & fghijk & 14.8 & ghijk & 20.8 & $\mathrm{ij}$ \\
\hline S3H3 & 70 & fgh & 3.11 & efghi & 3.12 & defghi & 15.8 & defgh & 22.02 & ghi \\
\hline S3H4 & 74 & cde & 3.42 & def & 3.39 & bcde & 16.5 & bcdef & 23.22 & efg \\
\hline S3H5 & 76 & bcd & 3.65 & cde & 3.72 & $a b c$ & 16.9 & bcde & 24.5 & de \\
\hline S4H1 & 63 & $\mathrm{jkl}$ & 2.45 & $\mathrm{jkl}$ & 2.52 & $\mathrm{jkl}$ & 13.7 & $\mathrm{kl}$ & 16.7 & $\mathrm{~nm}$ \\
\hline $\mathrm{S} 4 \mathrm{H} 2$ & 65 & ijk & 2.65 & hijkl & 2.72 & ijkl & 14.5 & hijkl & 17.4 & $\operatorname{lm}$ \\
\hline S4H3 & 67 & hi & 2.98 & fghij & 3.05 & efghi & 15.3 & fghij & 18.3 & $\mathrm{kl}$ \\
\hline S4H4 & 71 & efg & 3.32 & defg & 3.36 & bcde & 16 & defgh & 19.5 & $\mathrm{jk}$ \\
\hline S4H5 & 74 & cde & 3.52 & cdef & 3.59 & bcd & 16.6 & bcdef & 20.8 & $\mathrm{ij}$ \\
\hline S5H1 & 59 & 1 & 2.15 & 1 & 2.22 & 1 & 13.1 & 1 & 14.5 & o \\
\hline $\mathrm{S} 5 \mathrm{H} 2$ & 61.5 & $\mathrm{kl}$ & 2.35 & $\mathrm{kl}$ & 2.42 & $\mathrm{kl}$ & 13.9 & $\mathrm{jkl}$ & 15.5 & no \\
\hline S5H3 & 65.5 & $\mathrm{ij}$ & 2.68 & hijkl & 2.75 & hijk & 15.1 & fghijk & 16.7 & $\mathrm{~nm}$ \\
\hline S5H4 & 69.5 & fgh & 2.99 & fghij & 3.06 & efghi & 15.8 & defgh & 17.6 & $\operatorname{lm}$ \\
\hline S5H5 & 72.5 & def & 3.22 & efgh & 3.29 & cdefg & 16.4 & bcdefg & 19.1 & $\mathrm{k}$ \\
\hline
\end{tabular}

Means with at least one common alphabet have not significant differences based on Duncan's multiple range test at $5 \%$ probability level 
The S1H5 treatment composition also had the longest roots $(18.5 \mathrm{~cm})$, but they were not significantly different from those of the S2H4, S1H3, S1H4, and S2H5 treatment compositions. The shortest roots $(13.1 \mathrm{~cm})$ were also observed in the $\mathrm{S} 5 \mathrm{H} 1$ treatment composition, but they were not significantly different from those in the $\mathrm{S} 4 \mathrm{H} 2, \mathrm{~S} 5 \mathrm{H} 2$, $\mathrm{S} 4 \mathrm{H} 1$, and $\mathrm{S} 3 \mathrm{H} 1$ treatment compositions.

\section{Leaf length, leaf width and leaf area}

ANOVA results on leaf length, leaf width and leaf area index, are presented in Table 2. Results obtained from comparing the means of the interactive effects (Table 3) revealed that the S1H5 treatment composition had the largest leaf area index $\left(81.5 \mathrm{~mm}^{2}\right)$, which was not significantly different from those of the S2H5 and S1H4 treatments. The smallest leaf area index $\left(59 \mathrm{~mm}^{2}\right)$ belonged to the $\mathrm{S} 5 \mathrm{H} 1$ treatment composition, which was not significantly different from those of the $\mathrm{S} 5 \mathrm{H} 2$ and $\mathrm{S} 4 \mathrm{H} 1$ treatment compositions.

The largest leaf width $(4.64 \mathrm{~mm})$ was found in the S1H5 treatment composition, but it was not significantly different from those of the $\mathrm{S} 1 \mathrm{H} 4$ and $\mathrm{S} 1 \mathrm{H} 3$ treatment compositions. The smallest leaf width $(2.15 \mathrm{~mm})$ was observed in the $\mathrm{S} 5 \mathrm{H} 1$ treatment compositions, but it was not significantly different from those of the S3H1, S4H1, $\mathrm{S} 4 \mathrm{H} 2, \mathrm{~S} 5 \mathrm{H} 2, \mathrm{~S} 5 \mathrm{H} 3$ treatment compositions.

The treatment composition S1H5 enjoyed the longest leaves $(4.17 \mathrm{~cm})$, which was not significantly different from those in the $\mathrm{S} 2 \mathrm{H} 5, \mathrm{~S} 1 \mathrm{H} 4$, and $\mathrm{S} 3 \mathrm{H} 5$ treatment compositions. The shortest leaves $(2.22 \mathrm{~cm})$ were that of the $\mathrm{S} 5 \mathrm{H} 1$ treatment composition, but they were not significantly different from those of the S4H1, S4H2, $\mathrm{S} 5 \mathrm{H} 2$, and $\mathrm{S} 3 \mathrm{H} 1$ treatment compositions.

\section{Photosynthesis and transpiration}

Significant interaction was observed in terms of the traits being studied, at $1 \%$ probability level (Table 4). Based on the results the highest rate of photosynthesis $\left(24.04 \mu \mathrm{molCO}_{2} \mathrm{~m}^{-2} \mathrm{~s}^{-1}\right)$ and of transpiration $\left(2.85 \mathrm{mmol} \mathrm{H}_{2} \mathrm{O}_{2} \mathrm{~m}^{-2} \mathrm{~s}^{-1}\right)$ were produced in $\mathrm{S} 1 \mathrm{H} 5$ treatment; whereas the lowest values produced in $\mathrm{S} 5 \mathrm{H} 1$ treatments and were as low as $5.67 \mu \mathrm{molCO}_{2} \mathrm{~m}^{-2} \mathrm{~s}^{-1}$ and $0.65 \mathrm{mmol} \mathrm{H}_{2} \mathrm{O}_{2} \mathrm{~m}^{-2} \mathrm{~s}^{-1}$, respectively (Figs. 3 and 4).

\section{Stomatal conductance and substomatal cavity $\mathrm{CO}_{2}$ concentration}

Results from analysis of variance on these traits are shown in Table 4. There was a significant interaction between the salinity and humic acid factors in terms of the traits. Among the treatment levels, S1H5 produced the highest $\left(0.280 \mathrm{molCO}_{2} \mathrm{~m}^{-2} \mathrm{~s}^{-1}\right)$ stomatal conductance and lowest $(85 \mathrm{ppm})$ substomatal cavity $\mathrm{CO}_{2}$ concentration. In contrast, $\mathrm{S} 5 \mathrm{H} 1$ produced the lowest $\left(0.013 \mathrm{molCO}_{2} \mathrm{~m}^{-2} \mathrm{~s}^{-1}\right)$ stomatal conductance and highest (406 ppm) substomatal cavity $\mathrm{CO}_{2}$ concentration (Figs. 5 and 6 ).

\section{Organic matter percentage}

There was a significant interaction between the factors in terms of the organic matter percentage, at $1 \%$ probability level (Table 5). The highest $(89.69 \%$ on average) and lowest (69.46\% on average) organic matter percentage were produced in S2H3 and S4H5 treatments, respectively (Fig. 7). 
Table 4. Analysis of variance (mean squares) on Photosynthesis traits of Khuzestani savory under effects of salinity and humic acid

\begin{tabular}{|c|c|c|c|c|c|}
\hline & df & $\begin{array}{c}\text { Substomatal } \mathrm{CO}_{2} \\
(\mathrm{ppm})\end{array}$ & $\begin{array}{c}\text { Stomatal } \\
\text { conductance } \\
\left(\mathrm{mol} \mathrm{CO}_{2} \mathbf{~ m}^{-2} \mathbf{s}^{-1}\right)\end{array}$ & $\begin{array}{c}\text { Transpiration } \\
\left(\mathbf{m m o l ~} \mathrm{H}_{2} \mathrm{O}_{2} \mathbf{m}^{-2} \mathbf{s}^{-1}\right)\end{array}$ & $\begin{array}{c}\text { Photosynthesis } \\
\left(\mu \mathrm{mol} \mathrm{CO} \mathrm{m}^{-2} \mathbf{s}^{-1}\right)\end{array}$ \\
\hline Rep & 3 & 216 & 0.00006 & 0.003 & 0.007 \\
\hline Salinity (S) & 4 & $237077 * *$ & $0.10^{* *}$ & $5.41 *$ & $555.7 * *$ \\
\hline Humic acid (H) & 4 & $4967 * *$ & $0.015^{* *}$ & $1.52 * *$ & $39 * *$ \\
\hline $\mathbf{S} \times \mathbf{H}$ & 16 & $555^{* *}$ & $0.0002 * *$ & $0.04 * *$ & $0.64 * *$ \\
\hline Error & 72 & 130 & 0.00006 & 0.001 & 0.003 \\
\hline CV\% & & 4.18 & 0.85 & 2.15 & 0.41 \\
\hline
\end{tabular}

$\mathrm{ns}, *$ and $* *$ stand for non-significant, significant at 5 and $1 \%$ probability levels, respectively

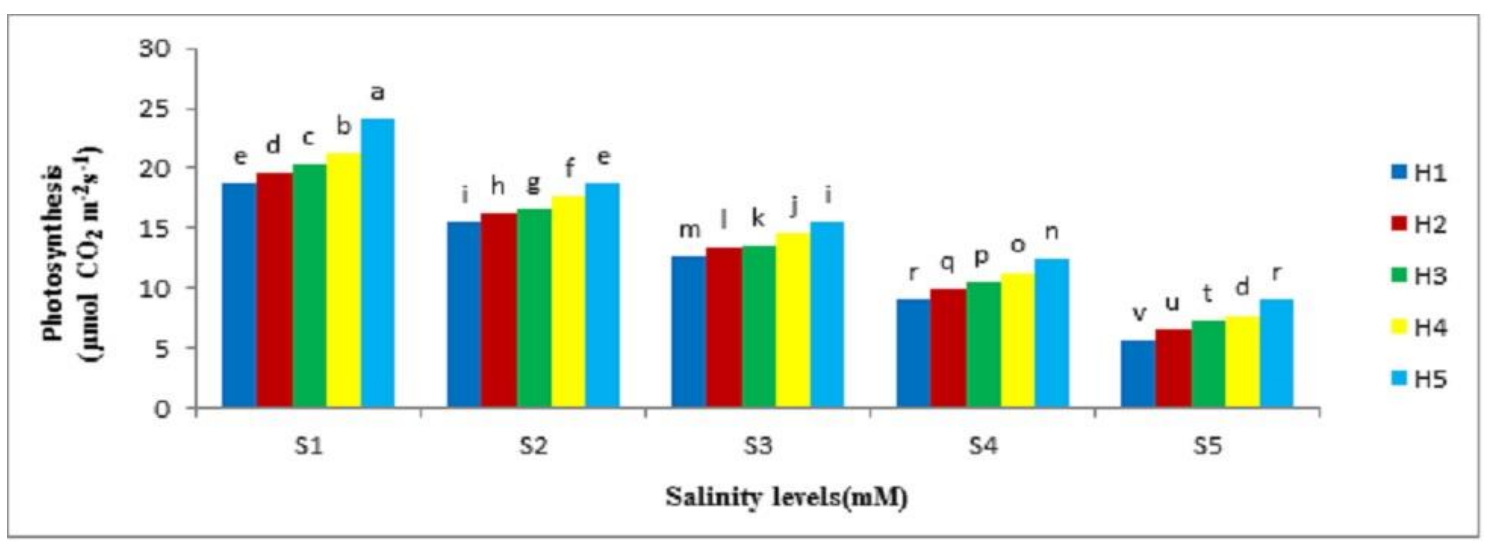

Figure 3. Interaction of salinity and humic acid on photosynthesis rate of Khuzestani savory (salinity (S) levels including 0,25, 50, 75 and $100 \mathrm{mM}$ of $\mathrm{NaCl}$ and humic acid (H) levels including 0 (hydropriming), 10, 20, 30 and $40 \mathrm{mg} / \mathrm{kg}$ soil, as explained in Table 1). Means with at least one common alphabet have not significant differences based on Duncan's multiple range test at $5 \%$ probability level

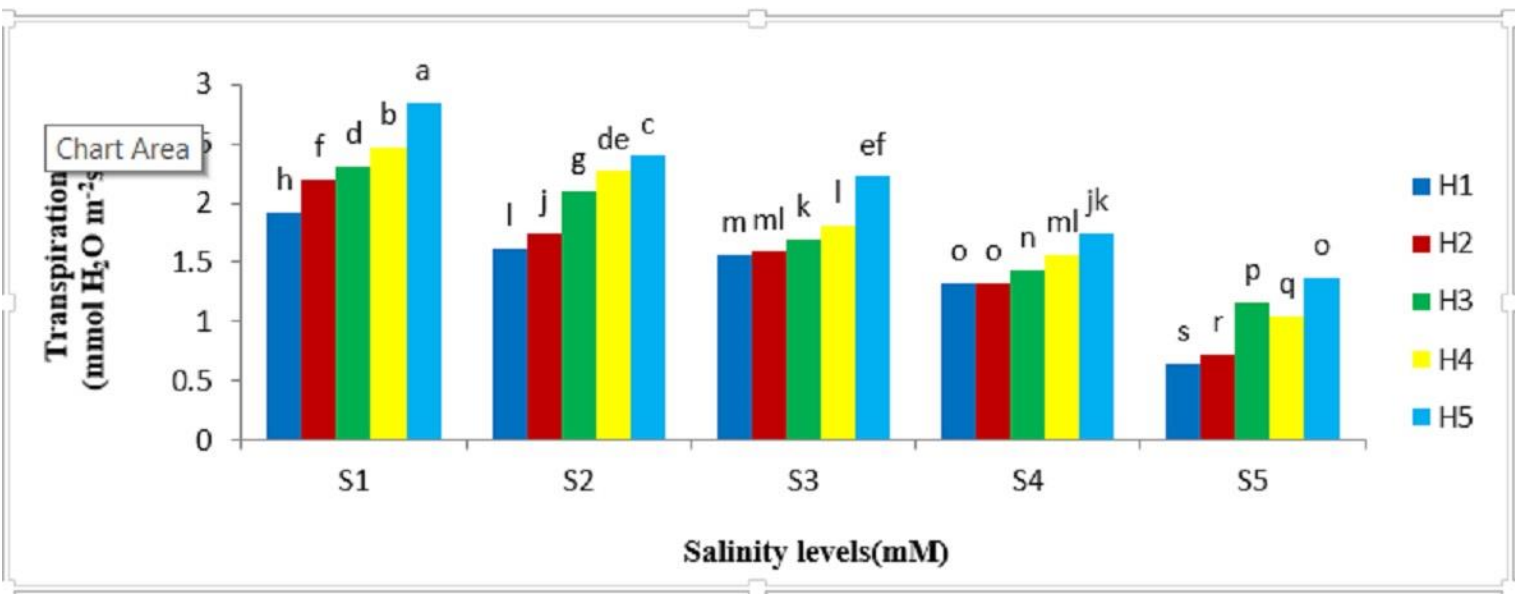

Figure 4. Interaction of salinity and humic acid on transpiration rate (salinity $(S)$ levels including 0, 25, 50, 75 and $100 \mathrm{mM} \mathrm{NaCl}$ and humic acid (H) levels including 0 (hydropriming), 10,20,30 and $40 \mathrm{mg} / \mathrm{kg}$ soil, as explained in Table 1). Means with at least one common alphabet have not significant differences based on Duncan's multiple range test at 5\% probability level 


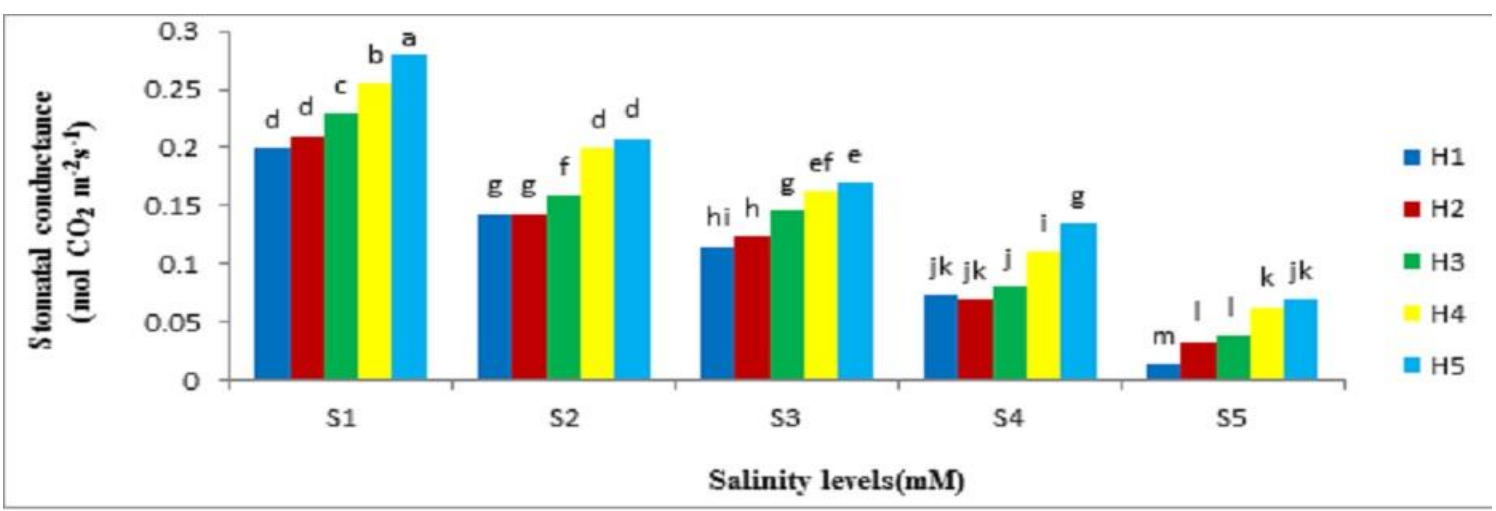

Figure 5. Interaction of salinity and humic acid on stomatal conductance (salinity $(S)$ levels including 0, 25, 50, 75 and $100 \mathrm{mM}$ of $\mathrm{NaCl}$ and humic acid (H) levels including $\mathrm{O}$ (hydropriming), 10,20, 30 and $40 \mathrm{mg} / \mathrm{kg}$ soil, as explained in Table 1). Means with at least one common alphabet have not significant differences based on Duncan's multiple range test at 5\% probability level

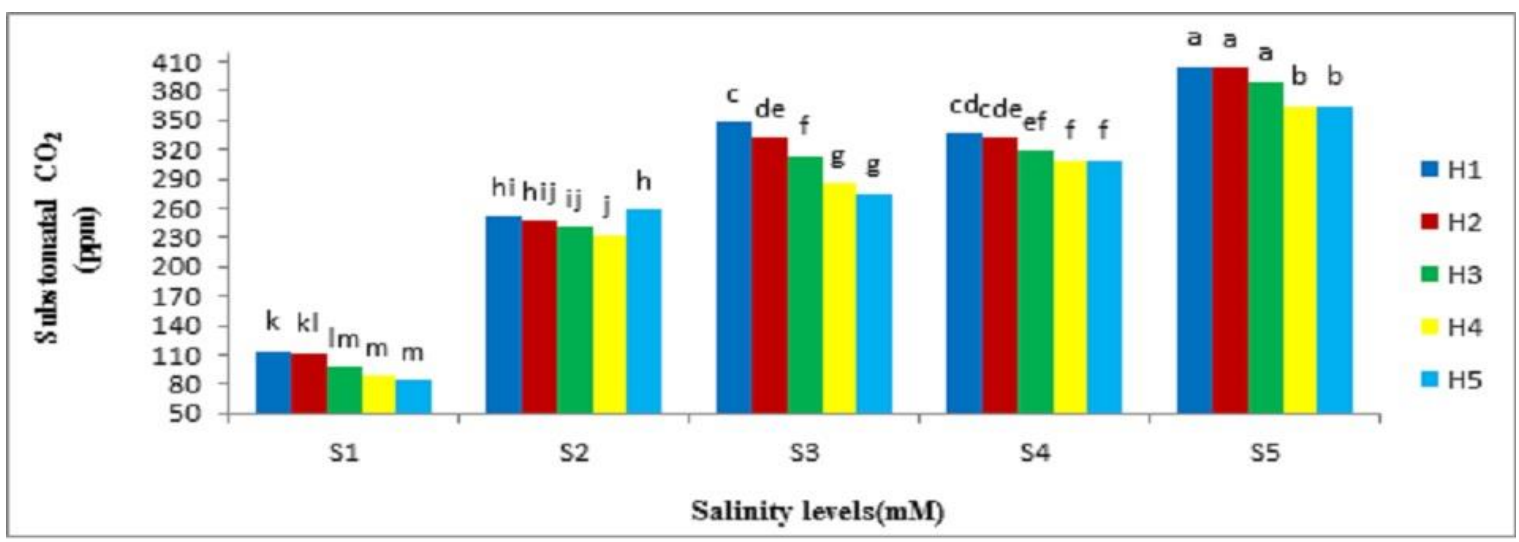

Figure 6. Interaction of salinity and humic acid on substomatal $\mathrm{CO}_{2}$ (salinity (S) levels including 0, 25, 50, 75 and $100 \mathrm{mM}$ of $\mathrm{NaCl}$ and humic acid ( $\mathrm{H}$ ) levels including $\mathrm{O}$ (hydropriming), 10, 20, 30 and $40 \mathrm{mg} / \mathrm{kg}$ soil, as explained in Table 1). Means with at least one common alphabet have not significant differences based on Duncan's multiple range test at 5\% probability level

Table 5. Analysis of variance (mean squares) of traits such as RWC of leaf, organic matter percentage and ash percentage of Khuzestani savory under the effects of salinity and humic acid

\begin{tabular}{c|c|c|c|c}
\hline & df & RWC of leaf) \%( & $\begin{array}{c}\text { Organic matter } \\
\text { percentage }\end{array}$ & Ash percentage \\
\hline Rep. & 3 & 0.514 & 0.96 & 0.23 \\
Salinity (S) & 4 & $479.15^{* *}$ & $208^{* *}$ & $137.2^{* *}$ \\
Humic acid (H) & 4 & $51.04^{* *}$ & $7.9 * *$ & $28.4^{* *}$ \\
S $\times$ H & 16 & $10.60^{* *}$ & $86.6^{* *}$ & $39.5 * *$ \\
Error & 72 & 0.46 & 1.66 & 0.50 \\
CV\% & & 0.79 & 1.55 & 4.61 \\
\hline
\end{tabular}

$\mathrm{ns}, *$ and $* *$ stand for non-significant, significant at 5 and $1 \%$ probability levels, respectively 


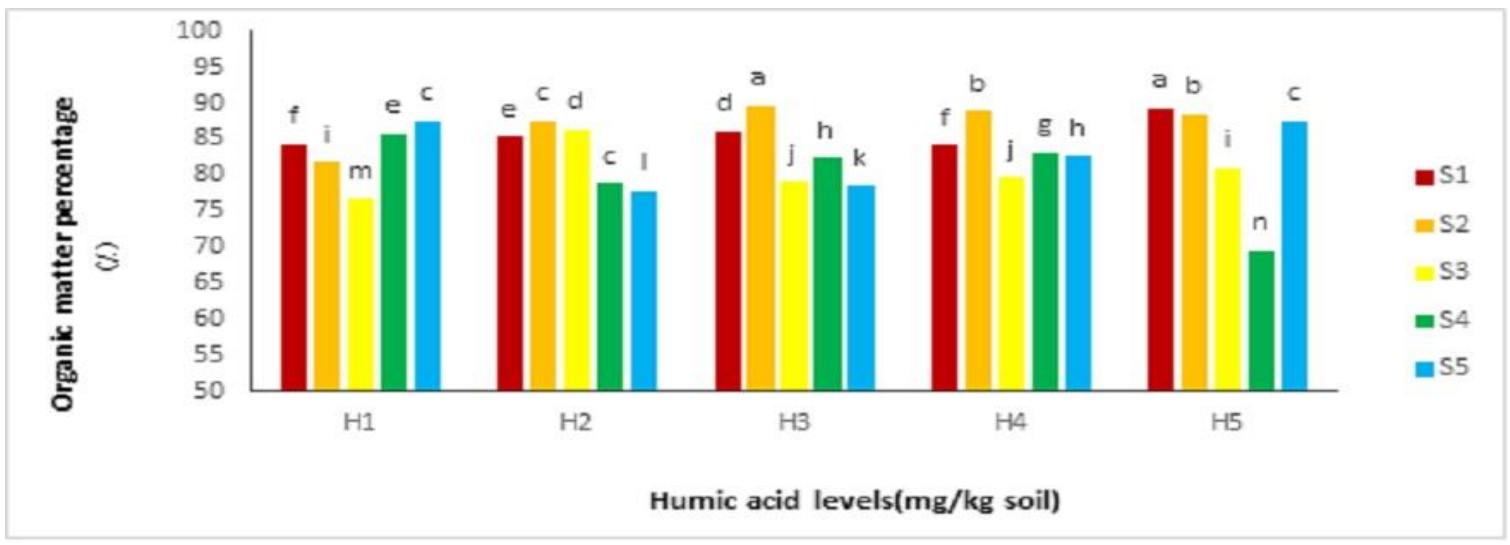

Figure 7. Interaction of salinity and humic acid on organic matter percentage (salinity $(S)$

levels including 0, 25, 50,75 and $100 \mathrm{mM} \mathrm{NaCl}$ and humic acid $(\mathrm{H})$ levels including 0 (hydropriming), 10, 20, 30 and $40 \mathrm{mg} / \mathrm{kg}$ soil, as explained in Table 1). Means with at least one common alphabet have not significant differences based on Duncan's multiple range test at 5\% probability level

\section{Ash percentage}

Results from analysis of variance revealed that there was a significant interaction between the salinity and humic acid factors, at $1 \%$ probability level (Table 5). The highest (24.37\% on average) and lowest (10.35\% on average) ash percentages were produced in $\mathrm{S} 5 \mathrm{H} 2$ and $\mathrm{S} 1 \mathrm{H} 5$ treatments, respectively (Fig. 8).

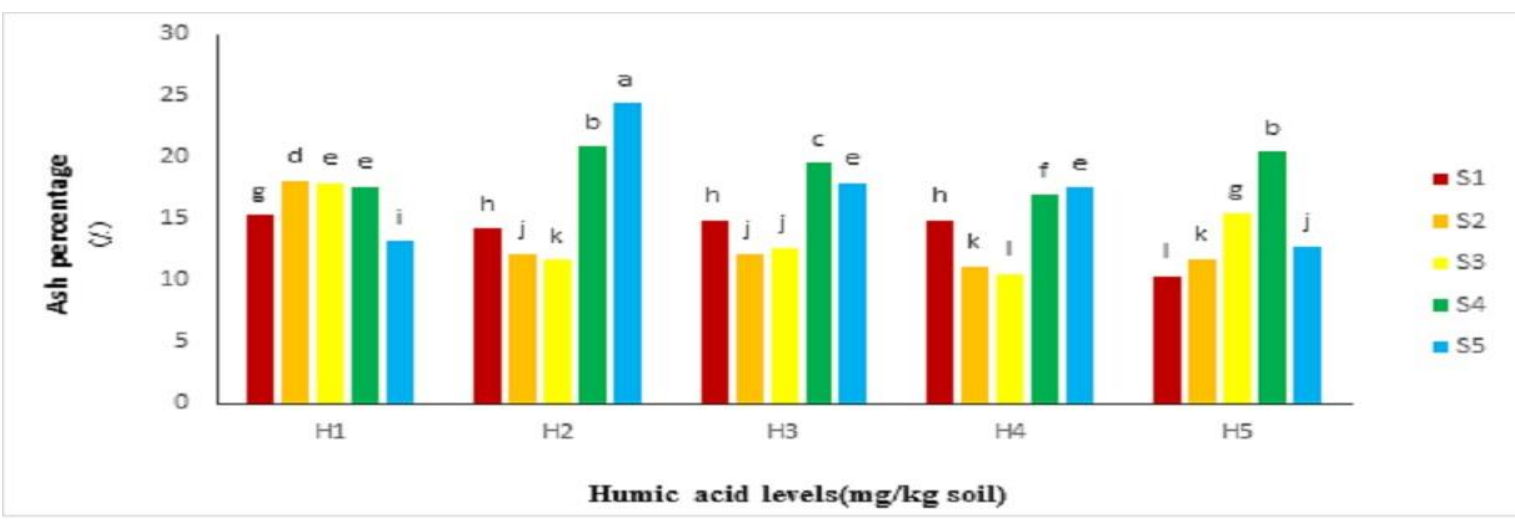

Figure 8. Interaction of salinity and humic acid on ash percentage (salinity $(S)$ levels including $0,25,50,75$ and $100 \mathrm{mM} \mathrm{NaCl}$ and humic acid (H) levels including 0 (hydropriming), 10, 20,

30 and $40 \mathrm{mg} / \mathrm{kg}$ soil, as explained in Table 1). Means with at least one common alphabet have not significant differences based on Duncan's multiple range test at 5\% probability level

\section{Relative water content $(R W C)$ of leaf}

Results revealed that there was a significant interaction between the salinity and humic acid factors, at $1 \%$ probability level (Table 5). Based on the results, S1H5 treatment produced the highest $(93.01 \%$ on average), whereas $\mathrm{S} 5 \mathrm{H} 1$ treatment the lowest (70.94\% on average) RWC of leaf; representing a reduction as much as $24 \%$ (Fig. 9). 


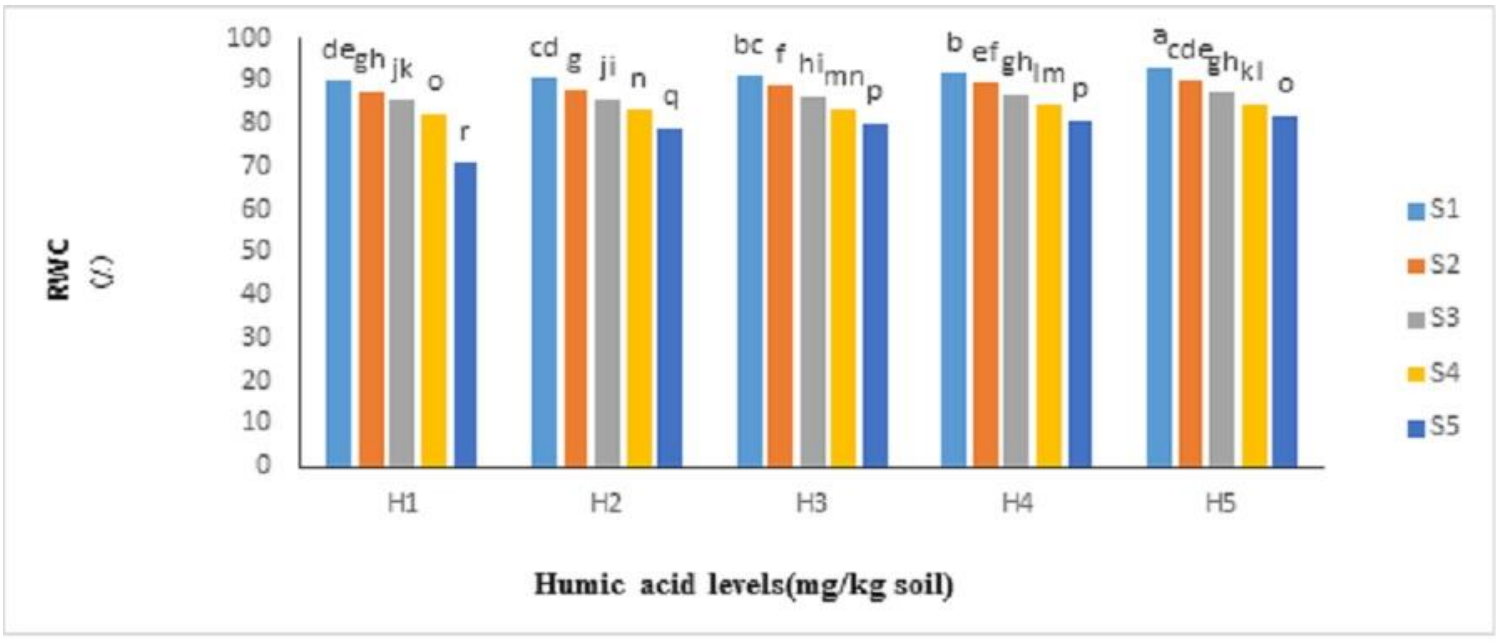

Figure 9. Interaction of salinity and humic acid on RWC (salinity (S) levels including 0, 25, 50, 75 and $100 \mathrm{mM} \mathrm{NaCl}$ and humic acid (H) levels including 0 (hydropriming), 10, 20, 30 and 40 $\mathrm{mg} / \mathrm{kg}$ soil, as explained in Table 1). Means with at least one common alphabet have not significant differences based on Duncan's multiple range test at 5\% probability level

\section{Proline and soluble sugar}

Significant interaction was found between the salinity and humic acid factors in terms of proline and soluble sugar traits, at $1 \%$ probability level (Table 6). Results showed that $\mathrm{S} 5 \mathrm{H} 1$ and $\mathrm{S} 5 \mathrm{H} 5$ treatments produced the highest proline content $(0.334 \mathrm{mg} / \mathrm{g}$ in fresh weight $)$ and highest soluble sugar content $(2.098 \mathrm{mg} / \mathrm{g}$ in dry matter), respectively. Whereas, $\mathrm{S} 1 \mathrm{H} 5$ and $\mathrm{S} 1 \mathrm{H} 1$ (control) treatments produced the lowest $(0.155 \mathrm{mg} / \mathrm{g}$ in fresh weight $)$ and lowest soluble sugar content $(0.808 \mathrm{mg} / \mathrm{g}$ in dry matter), respectively (Figs. 10 and 11).

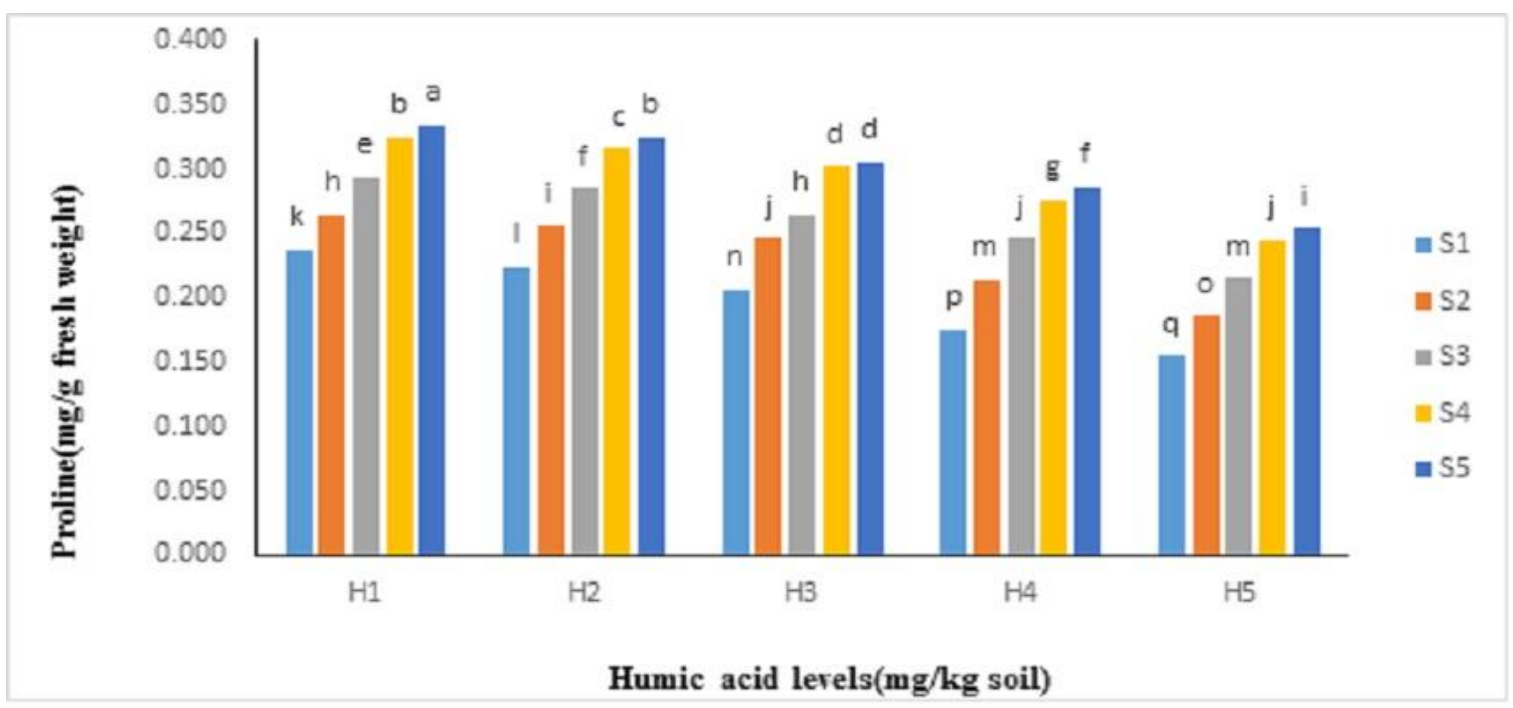

Figure 10. Interaction of salinity and humic acid on proline content (salinity $(S)$ levels including 0, 25, 50, 75 and $100 \mathrm{mM} \mathrm{NaCl}$ and humic acid (H) levels including 0 (hydropriming), 10, 20, 30 and $40 \mathrm{mg} / \mathrm{kg}$ soil, as explained in Table 1). Means with at least one common alphabet have not significant differences based on Duncan's multiple range test at 5\% probability level 


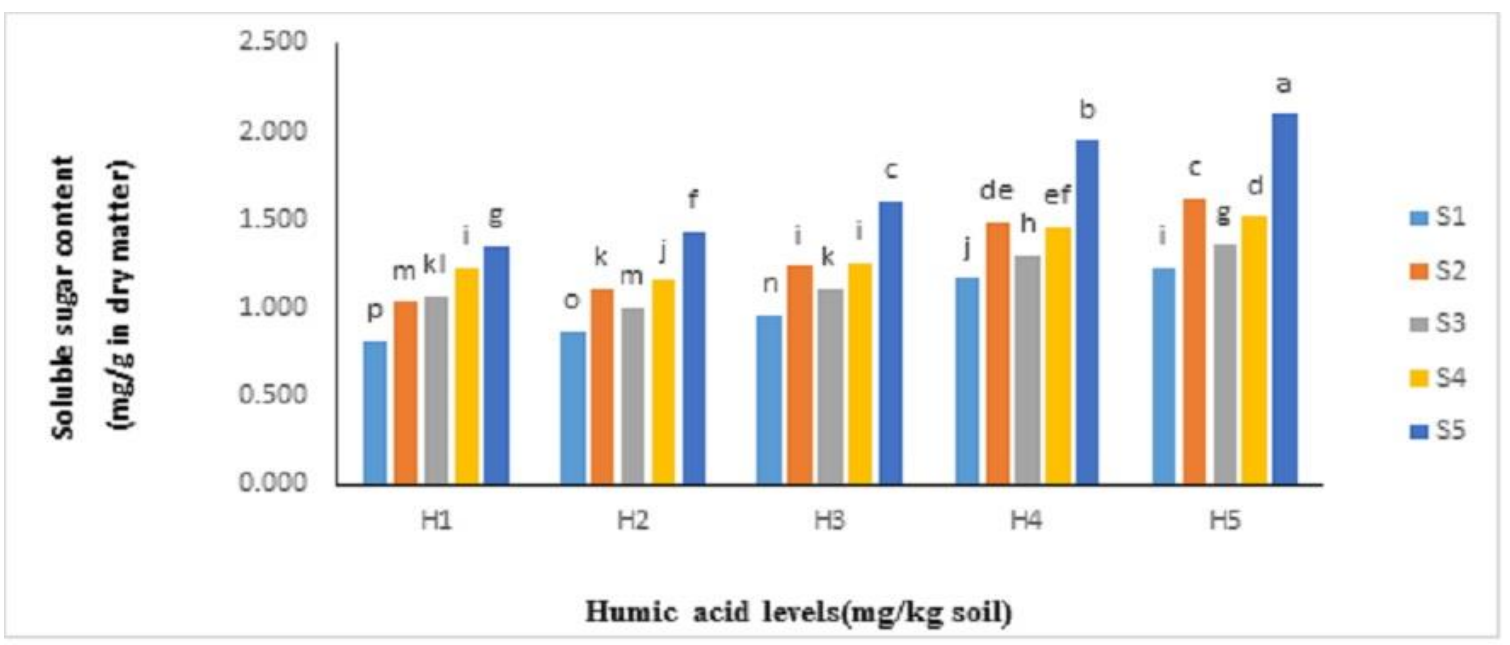

Figure 11. Interaction of salinity and humic acid on soluble sugar content (salinity (S) levels including 0, 25, 50, 75 and $100 \mathrm{mM} \mathrm{NaCl}$ and humic acid (H) levels including 0 (hydropriming), 10, 20, 30 and $40 \mathrm{mg} / \mathrm{kg}$ soil, as explained in Table 1). Means with at least one common alphabet have not significant differences based on Duncan's multiple range test at 5\% probability level

Table 6. Analysis of variance (Mean Squares) on biochemical traits (proline and soluble sugar contents) of Khuzestani savory under the effects of salinity and humic acid

\begin{tabular}{c|c|c|c}
\hline & df & $\begin{array}{c}\text { Proline } \\
\text { (mg/g of fresh weight) }\end{array}$ & $\begin{array}{c}\text { Soluble sugar } \\
\text { (mg/g in dry matter) }\end{array}$ \\
\hline Rep. & 3 & 0.000024 & 0.0006 \\
Salinity (S) & 4 & $0.035^{* *}$ & $1.27^{* *}$ \\
Humic acid (H) & 4 & $0.020^{* *}$ & $0.90^{* *}$ \\
S $\times$ H & 16 & $0.0003^{* *}$ & $0.02^{* *}$ \\
Error & 72 & 0.00009 & 0.0009 \\
CV\% & & 1.20 & 2.39 \\
\hline
\end{tabular}

$\mathrm{ns}, *$ and $* *$ represent non-significant, and significant at $5 \%$ and $1 \%$ probability levels

\section{Discussion}

\section{Length of stem and root}

Plant growth and height invariably depends on the environmental conditions in which it grows. One of these conditions is the availability of sufficient water to the plant. Otherwise, decreased height can be resulted by decreased turgor pressure of the cells that leads to decreased length of each individual cell. The osmotic stress resulted from salinity stress during the early stages leads to decreased water content of the cells caused by compromised water uptake. If salt accumulation continued to the next stages and its concentration in plant tissues reached to a toxic level, premature aging of leaves and decreased photosynthesizing area of leafs may ensue, which in turn leads to decreased growth and lengthening of the cells (Munnz et al., 2006).

Amiraa and Abdul (2011) stated that although increased salinity stress led to a severe decrease in root and stem lengths, it increased the protein content of the samples . application of humic acid leads to increased height in plant by enabling it to uptake 
micronutrients more efficiently. Acid humic can be used as a growth regulator, because it has an increasing effect on auxins, gibberellins and cytokinins, higher amounts of which cause lengthening of stems and improve plant growth. Results from the present study are consistent with those of study by Jariene et al. (2007) on pumpkin and of study by Ebrahimi and Miri Karbasak (2016) on Spaghetti.

Moreover, humic acid is characterized by its chelating effect on various nutrients such as sodium, potassium, magnesium, zinc, calcium, iron, copper, among others, that ensures sufficient nutrient supply to the plant and cause increased length and weight of primary root and formation of new lateral roots (Abedi and Pakniat, 2010). Humic acid application to pepper seedlings (Capsicum annum cv Derme) grown in pots and under salinity stress showed that in 1000 and $2000 \mathrm{mg} / \mathrm{Kg}$ dosages it increased traits such as stem and root lengths and wet and dry weights (Gulser et al., 2010).

Study on effects of irrigation regimes and humic acid spraying on some of the morphological and physiological traits of savory revealed that plants sprayed with $300 \mathrm{mg} / \mathrm{L}$ dosage of humic acid had the highest growth indices. More specifically, the highest values for plant height, dry and wet weights, leaf length and carbohydrate content were obtained in " $100 \%$ irrigation $+300 \mathrm{mg} / \mathrm{L}$ humic acid" treatment (Sabouri et al., 2017). Humic acid increases plant growth and height through hormonal effects, boosting cellular metabolisms of plants, and improving uptake of nutrients by acting as a chelating agent (Salimon et al., 2012). Jumat et al. (2012) in their research into the impact of humic and folic acids on wheat reported that effect of humic acid fertilizer on the plant height was significant $(\mathrm{P}<0.01)$.

\section{Leaf length, leaf width and leaf area}

Decreased leaf area may be due to the direct effect of salt on the cell division rate or to the shortened cell formation period. Seemingly, in glycophytes salt transport rate from root to shoot is higher than salt capacity of leafs; this slows down leaf growth and finally causes it to die (Parihar et al., 2015). There are three possible reasons for the decreased leaf area including decreased number of single-leafs, decreased production in young leafs and falling off of old leafs (Fahad et al., 2015).

Study on impacts of salinity from sodium chloride on savory has revealed that increased salinity stress has a decreasing effect on the growth parameters of the plant including leaf area; leaf water content; dry weight of root, stem and leaf; and chlorophyll and carotenoid contents. In contrast, it had an increasing effect on the proline and soluble sugar contents of the samples (Najafi et al., 2010). Root is the first plant organ affected by salinity stress and most of the times plays an important part in preventing salinity to reach the leafs. Leaf size depends on the number and size of its individual cells. Early leaf development stages are not sensitive to drought and salinity stresses; however leaf expansion is heavily influenced by salinity. Under salinity conditions leaf cellular swelling is decreased heavily, through which the stress can negatively affect leaf expansion (Razavizadeh and Rostami, 2003).

Based on the results from a study on myrtle plant (Myrthus communis) there was a significant difference between the salinity treatments in terms of most of the traits including plant height, leaf length and leaf width $(\mathrm{P}<0.01)$. More specifically, the highest $(1.69 \mathrm{~cm})$ mean value of leaf length belonged to control treatment; whereas the lowest $(1.28 \mathrm{~cm}$ ) value for the trait was produced at the highest stress level of $6 \mathrm{dS} / \mathrm{m}$ ). Furthermore, leaf width decreased as the salinity stress level and its application period increased (Vafadar et al., 2018). 
In a research, savory sprayed with $300 \mathrm{mg} / \mathrm{L}$ of humic acid produced the highest growth indices. More specifically, the highest values for traits such as plant height, wet and dry weights, leaf length and carbohydrate content were produced in " $100 \%$ irrigation level $+300 \mathrm{mg} / \mathrm{L}$ humic acid spraying" treatment (Sabouri et al., 2017). High salinity can decrease leaf area through decreased water uptake. In addition to decreasing leaf area, salinity stress decreases dry weight of the plant, which is responsible for decreased photosynthetic area and hormonal imbalance of the plant. Salinity stress increases $\mathrm{CO}_{2}$ concentration of substomatal cavity through decreased stomatal conductance and diminishes dry weight of plant by preventing biochemical activities and sucrose synthesis (Salimi et al., 2014).

Based on the results from a study on Moldavian dragonhead plant, leaf length increased significantly with the increasing salinity stress, while the highest $(5.66 \mathrm{~cm})$ value for the trait was produced in "without salinity stress $+200 \mathrm{mM}$ humic acid" treatment. Application of $200 \mathrm{mM}$ humic acid and $100 \mathrm{mM}$ ascorbic acid improved this trait at 50 and $100 \mathrm{mM}$ salinity levels, respectively (Narimani et al., 2018).

\section{Photosynthesis and transpiration}

The reason for decreased photosynthetic activity under salinity stress is twofold: dehydration of cell membrane that reduces its $\mathrm{CO}_{2}$ permeability and the reduced $\mathrm{CO}_{2}$ absorption of leaf that causes stomata to close. Furthermore, salt toxicity increases the salinity-induced sensitivity; consequently, activity of the induced enzymes changes due to the structural changes in cytoplasm. At the end, the negative feedback of reduced SINK activity and reduced water potential have also been reported as the photosynthesisdecreasing factors (Negrao et al., 2017).

Reduced photosynthetic activity depends on two other aspects of salinity including the final salt concentration and availability of the other ions. High salinity concentration of soil and water leads to increased osmotic potential, consequently $\mathrm{Na}^{+}$ions permeate into cytosol and inactivate electron transport in photosynthesis and transpiration. Moreover, there has been report that under high salinity condition the high concentration of sodium and reduced concentration of potassium lead to inhibition of photosystem II and reduced Rabiesco carboxylation, dilation of thylakoid membranes, reduced number and depth of grana and finally reduced number of mesophyll cells (Parihar et al., 2015).

A great number of physiological studies suggest that salinity impedes plant growth through decreasing photosynthesis. It is known that decreased photosynthesis due to salinity stress involves numerous intervening factors such as cell dehydration and subsequently its reduced permeability to $\mathrm{CO}_{2}$, toxicity caused by accumulation of sodium and chloride elements, decreased $\mathrm{CO}_{2}$ concentration due to stomatal closure, accelerated aging process due to salt accumulation (leaf fall), changed activity of the enzymes due to structural changes in cytoplasm, and plant failure to utilize assimilates due to reduced growth (Negrao et al., 2017).

However, owing to the numerous parts it can play in improvement of plant growth, humic acid could diminish the effect of salinity stress on the photosynthetic activity of savory. It has been reported that humic acid increased photosynthetic activity of plant through the increased activity of RuBisCO enzyme. Moreover, humic acid improves longevity of the photosynthetic tissues and increases grain yield. Humic acid increases nutrient content of crops through improved synthesis of carbohydrate, protein and vitamin in the plant and its positive effect on the photosynthetic aspects (Sharif, 2002). There are 
also numerous reports concerning the impacts of humic acid on decreasing transpiration rate under the stressed condition.

Under salinity stress condition, excessive diffusion of $\mathrm{Na}^{+}$ions into the cell inactivates photosynthetic electron transport systems; this in turn leads to decreased photosynthetic activity of the plant (Allahverdiev et al., 1998). In addition, under the salinity stress $\mathrm{Na}^{+}$ ion competes with other ions, particularly potassium, which leads to decreased absorption of potassium by the plant as well as decreased cellular potassium/sodium ratio; this will negatively influence photosynthesis and development of the plant (Parida and Das, 2005). Salinity stress leads to nutrient imbalance, destruction of cellular organelles and compromised photosynthesis and transpiration in the plants (Aroca et al., 2013).

In a study conducted by Khalvandi et al. (2018), salinity stress led to a significant decrease in transpiration rate of peppermint. More specifically, an increase from 0 to $9 \mathrm{dS} / \mathrm{m}$ in salinity level decreased the transpiration rate by $56.49 \%$. This means that in response to salinity stress, in order to minimize its impacts and maintain water balance of its leaves, the plant closed its stomata and prevented water loss through transpiration (Khalvandi et al., 2018).

Humic compounds influence plant growth and development both directly and indirectly. As for their indirect impacts, humic compounds improve soil fertility through by increasing beneficial microorganisms of soil, improving soil structure, increasing cationic exchange capacity and soil buffering capacity; whereas, their direct impacts are through increased photosynthesis, transpiration, and synthesis of proteins etc. (Saruhan et al., 2011). Molecules of humic acid prevent evaporation by binding to water molecules. Furthermore, molecules of folic acid (sub molecular part of humic acid) contribute to maintaining tissue hydration of plants as they penetrate into plant tissues and decrease transpiration by binding to water molecules (Bronick and Lay, 2005). Researchers demonstrated that humic substances contribute to uptake of nutrients, particularly nitrogen, which in high amount can increase chlorophyll content and photosynthesis of plants and accelerate their growth (Khayyat et al., 2007). In sour tea, humic acid spraying caused improved mobility and efficiency of nutrients, increased zinc and iron content of leaf and consequently increased photosynthesis and synthesis of carbohydrate and protein (Minai and Heidari, 2013). Humic acid contributes to photosynthetic activity through increasing the activity of RuBisCO (Chamani et al., 2012).

\section{Stomatal conductance and substomatal cavity $\mathrm{CO}_{2}$ concentration}

It appears stomatal blockage under intensive stressed conditions contribute to reduction in stomatal conductance. Moreover, results have shown that decreased matter synthesis is mainly caused by reduced stomatal conductance; however, impacts of high salt concentrations on carboxylation efficiency should not be ignored (Ashraf and Harris, 2013). Reduced stomatal conductance under stressed conditions can be associated with low number and concentration of stomata. Researchers have argued that mesophyll cells in the plants subjected to salinity stress were smaller and more compact than those in control and even attributed the decreased $\mathrm{CO}_{2}$ distribution to this physiological and anatomical change. Reduced stomatal conductance is the main pathway of leaf dehydration under stressed condition and is accompanied by reduced $\mathrm{CO}_{2}$ absorption into the leaves and subsequently reduced photosynthesis. Another factor that can limit $\mathrm{CO}_{2}$ distribution to its fixation site (chloroplasts) is mesophyll conductance, which is reduced under the stressed conditions particularly in response to salinity stress; and when $\mathrm{CO}_{2}$ 
fails to make it to the sites of carbon fixation sites, reduced photosynthesis and stomatal conductance can ensue (Negrao et al., 2017).

Results from the present study concerning the substomatal $\mathrm{CO}_{2}$ revealed that increased $\mathrm{NaCl}$ concentration led to decreased stomatal conductance. However, substomatal $\mathrm{CO}_{2}$ rates exhibited an increasing trend, while there was a negatively significant correlation between them. Thus, it is expectable that in addition to reduced stomatal conductance, some other non-stomatal restrictions such as a potential damage to optical systems are influencing salinity-induced photosynthesis reduction.

Based on the results from a study on Moldavian dragonhead plant, stomatal conductance differed significantly at different levels of salinity stress in the absence of the stress relievers. Whereas, presence of humic acid and ascorbic acid led to a significant increase in this trait at all stressed levels, as compared to the control (absence of stress reliever) (Narimani et al., 2018).

Decreased water uptake induced by high salinity can result in decreased leaf area. In addition, salinity stress can cause a decrease in dry weight of plant; this in turn can cause decreased photosynthetic area as well as compromised hormonal balance inside the plant. Salinity stress leads to increased intrastomatal $\mathrm{CO}_{2}$ concentration through decreased stomatal conductance, and to diminished dry weight of plant by preventing biochemical activities and sucrose synthesis (Salimi et al., 2014).

\section{Organic matter percentage}

Researches in the field have shown that soil salinity leads to decreased growth and subsequently decreased plant biomass through primary and secondary impacts; curiously, plant organs such as root, stem and offshoot respond differently to salinity stress as they differ in terms of sensitivity to it (Setia et al., 2013). Under the stressed conditions, application of compounds such as humic acid can influence plant growth through changing physiology of the plant and improving the physical, chemical and biological properties of the soil. Furthermore, humic acid can directly influence plant growth by stimulating growth of both shoot and root systems of plant. Impact of humic acid is more prominent on root system, as it can improve its efficiency through increasing its volume. Lastly yet importantly, humic acid can increase uptake of nitrogen, potassium, calcium, magnesium and phosphorus by the plant (Balakunbahan and Rajamani, 2010).

\section{Ash percentage}

Ash percentage is indicative of minerals content of plant tissues; while uptake of minerals by root is increased under salinity stress conditions. Humic acid improves root growth and increases uptake of nutrients and their transport into the organs, while has a decreasing effect on charging of the ionic salts (Shaaban et al., 2009).

Product of burning the organic plants is nonorganic ash (minerals) and the lesser is the residual ash the higher is the plant's quality. Some medicinal plants vary relatively highly in terms of ash percentage, which is very helpful in plant quality assessment (Omidbaigi, 2004). Thus, it can be seen that application of humic acid led to decreased ash percentage, which represents high quality of the treatments.

\section{Relative water content $(R W C)$ of leaf}

Environmental stresses, particularly salinity stress, lead to reduction of available interstitial moisture through creating physiological drought so that plant water relations 
are compromised and water imbalance ensues. However, positive effect of humic acid fertilizers on enlargement of plant root and subsequently on its ability to uptake water and nutrients, make them a desirable tool to improve plant water status. This is consistent with the result of the present study, as humic acid led to the increase of RWC of leaf. Sinclair and Ludlow (1985) reported the normal range of RWC to be 85-95\%; in which, they believe water uptake by root and water loss through transpiration are in balance, so that the plant can maintain its natural functioning. Results from a study on peppermint revealed that increased salinity led to a significant decrease in RWC of all the treatments. This decrease is mainly associated with the decrease in stomatal conductance rate that leads to stomatal closing and decreased transpiration, and finally to decreased water uptake by the roots (Khalvandi et al., 2018).

Based on results of study by Beheshti and Tadayyon (2017) humic acid had a significant effect on RWC of leaf. More specifically, the highest RWC (83.6\%) was obtained in $6 \mathrm{~L} / \mathrm{ha}$ application of humic acid. Based on results from another study on Moldavian dragonhead plant the highest RWC (81\%) was produced at both $100 \mathrm{mg} / \mathrm{L}$ and $200 \mathrm{mg} / \mathrm{L}$ humic acid levels under without stress condition. Furthermore, as the stress level increased the value of trait decreased and reached to its lowest value $(56 \%)$ at 150 mmolar salinity stress in the absence of humic and ascorbic acids. However, in the same salinity stress level, application of 100 and $200 \mathrm{mg} / \mathrm{L}$ of humic acid and $200 \mathrm{mg} / \mathrm{L}$ of ascorbic acid is capable of improving the trait (Narimani et al., 2017).

\section{Proline and soluble sugar}

Proline is one of the active amino acids involved in osmoregulation. Accumulation of proline triggered by increased salinity and increased intracellular osmotic pressure is one of the mechanisms of salinity tolerance in plants. Since in plants proline is accumulated in response to salt and drought stresses, proline synthesis in plants may be the result of non-specific response to low water potential. Moreover, appropriation of more carbons to synthesize organic substances effective on osmoregulation such as proline, also can reduce plant growth (Ashraf and Foolad, 2007). Thus, increased synthesis of proline by the savory triggered by increased salinity may be one of the growth-reducing factors under the same condition. It has been reported that humic acid is capable of reducing the synthesis and accumulation of compounds compatible with cytoplasm such as proline.

Soluble sugars act as the osmoregulators, stabilizer of cell membrane and maintainer of cell turgidity. Actually, plants capable of accumulating higher amount of sugars under the stressed condition exhibit higher tolerance against the stress (Slama et al., 2007). Plants use various physiological mechanisms to deal with salinity stress such as storing sodium in vacuoles in order to reduce its toxic effects and producing osmolytes including glycine betaine, proline, soluble sugars, phenolic compounds etc. (Jouyban, 2012).

When under stress conditions, plants use proline as the source of energy, carbon and nitrogen to regenerate the damaged tissue (Najafi et al., 2010). As salinity level increases so does the amount of osmoregulators such as probline, which enable the plant to tolerate the environmental stresses. Proline is synthesized from glutamate and ornithine. Increased synthesis of proline is a type of osmoregulation strategy that may lead to reduced plant growth (Mirza Masoumzadeh et al., 2012). Reduced consumption of proline for protein synthesis under stressed condition may be another reason for proline accumulation (Mudgal et al., 2009). 
Study on effects of salinity stress of sodium chloride on savory revealed that increased salinity stress caused a severe decrease in growth parameters including leaf area; leaf water content; dry weights of root, stem and leaf; and in chlorophyll and carotenoid content of leaf. Whereas, increased salinity caused increase in proline and soluble sugar content of the samples (Najafi et al., 2010). In their study on savory grown under salinity stress Vojodi Mehrabani et al. (2017) concluded that savory is capable of tolerating salinity up the level as high as 50 mmolar without suffering a considerable decrease in its dry weight. Furthermore, as salinity stress increases so does the proline content of the samples. More specifically, in their study the highest proline contents of the samples were found at 100 mmolar and 150 mmolar concentrations of $\mathrm{NaCl}$; whereas control treatment produced the lowest proline content; which is consistent with the results of study by Akbari et al. (2013) concerning the proline content of savory samples under salinity stress. Furthermore, the highest soluble sugar content was produced at 100 and 150 mmolar $\mathrm{NaCl}$ concentrations.

Moreover, study by Najafi et al. (2010) on savory revealed that increased salt concentration led to increased soluble sugar content of the plant. Curiously, soluble sugars contribute to osmoregulation, and maintain membrane integrity and stability of the intracellular proteins.

Nouri et al. (2013) demonstrated that increased salinity led to increased proline content of stem in Shirazi chamomile, while the highest proline content was produced in $9.5 \mathrm{dS} / \mathrm{m}$ salinity treatment and the lowest value in control. Kafi et al. (2012) reported that increased content of soluble sugars under salinity stress condition may reveal that transport from above ground organs to the root of soluble carbohydrates has been compromised.

\section{Conclusion}

Salinity is one of the main environmental stresses in most parts of the globe that affect plant traits negatively. Based on the results from the present study, humic acid can alleviate the negative effects of salinity stress, while increasing concentrations of humic acid under salinity stress led to a significant increase in growth traits as compared with control. In conclusion, as water is becoming increasingly scarce and agricultural lands in arid and law rainfall areas are becoming increasingly saline, the importance of humic acid fertilizer as a tool to alleviate the harmful impacts of these agricultural and environmental challenges can never be overemphasized.

\section{Suggestions}

- Since Khuzestani savory is a wild species and its overexploitation may be accompanied by the danger of its extinction, it is necessary to conduct more experiments on expanding its cultivation. This will reduce its illegal harvest in nature and prevent its extinction.

- It is suggested that similar studies be carried out at higher salinity levels.

- The present research was conducted in a greenhouse. Therefore, it is suggested that studies be carried out at field level.

- It seems that long-term experiments are needed for more accurate studies on effects humic acid and salinity have on Khuzestani savory. 
- It is suggested that effects of other organic fertilizers and environmental stresses, and also their interactive effects, on this plant be determined, and also effects of organic and chemical fertilizers on it be compared.

- Since this is a native plant of Lorestan and Khuzestan Provinces, it is suggested similar studies should be conducted in other regions and climates to determine its adaptability to different conditions.

\section{REFERENCES}

[1] Abedi, T., Pakniyat, H. (2010): Antioxidant enzyme changes in response to drought stress in ten cultivars of oilseed rape (Brassica napus L.). - Czech Journal of Genetics and Plant Breeding 46(1): 27-34.

[2] Akbari, S., Kordi, S., Fatahi, S., Ghanbari, F. (2013): Physiological responses of Summer Savory under salinity stress. - International Journal of Agriculture and Crop Science 5: 1702-1708.

[3] Allahverdiev, S. R., Mavituna, M., Ganieva, R., Nafisi, S. (1998): Effects of salt stress and synthetic hormone polystimuline $\mathrm{K}$ on photosynthetic activity of Trianea bogotensis Karst. - Turkish Journal of Botany 22: 19-23.

[4] Amiraa, M. S., Abdul, Q. (2011): Effect of salt stress on plant growth and metabolism of bean plant Vicia faba (L.). - Journal of the Saudi Society of Agricultural Sciences 10: 715.

[5] Amirjani, M. R. (2010): Effect of $\mathrm{NaCl}$ on some physiological parameters of rice. - EJBS 3(1): 6-16.

[6] Aroca, R., Ruiz-Lozano, J. M., Zamarreno, A. M., Paz, J. A., Garcia-Mina, J. M., Pozo, M. J., Lopez-Raez, J. A. (2013): Arbuscular mycorrhizal symbiosis influences strigolactone production under salinity and alleviates salt stress in lettuce plants. Journal of Plant Physiology 170: 47-55.

[7] Ashraf, M. (1994): Breeding for salinity tolerance in plants. - Critical Review in Plant Science 13: 17-42.

[8] Ashraf, M., Foolad, M. R. (2007): Roles of glycine betaine and proline in improving plant abiotic stress resistance. - Environmental and Experimental Botany 59(2): 206-216.

[9] Ashraf, M. H. P. J. C., Harris, P. J. C. (2013): Photosynthesis under stressful environments: an overview. - Photosynthetica 51(2): 163-190.

[10] AOAC (1990): Official Methods of Analysis. 15th Ed. - Association of Official Analytical Chemists, Arlington, USA.

[11] Balakumbahan, R., Rajamani, K. (2010): Effect of biostimulants on growth and yield of Senna (Cassia angustifoliavar KKM.1). - Journal of Horticultural Science \& Ornamental Plants 2(1): 16-8.

[12] Bashan, Y., de-Bashan, L. E., Prabhu, S. R., Hernandez, J.-P. (2014): Advances in plant growth-promoting bacterial inoculant technology: formulations and practical perspectives (1998-2013). - Plant Soil 378: 1-33.

[13] Bates, L., Waldren, R., Teare, I. (1973): Rapid determination of free proline for waterstress studies. - Plant and Soil 39(1): 205-207.

[14] Bronick, E. J., Lai, R. (2005): Soil structure and management. A review. - Geoderma 124: 3-22.

[15] Calvo, P., Nelson, L., Kloepper, J. W., (2014): Agricultural uses of plant biostimulants. Plant Soil 383: 3-41.

[16] Chamani, F., Khodabandeh, N., Habibi, D., Asgharzadeh, D. F. (2012): Effect of salinity stress on yield and yield components in wheat, inoculated with growth promoting bacteria (Azotobacter chrocum, Azospirillio lipophorum, Pseudomonas putida) and humic acid. Agronomy and Plant Breeding. 8(1): 37-25. 
[17] Chaves, M. M., Flexas, J., Pinheiro, C. (2009): Photosynthesis under drought and salt stress: regulation mechanisms from whole plant to cell. - Annals of Botany 103: 551-560.

[18] Da Silva, E. C., Nogueira, R. J. M. C., De Araujo, F. P., De Melo, N. F., Neto, A. D. A. (2008): Physiological responses to salt stress in young umbu plants. - Environmental and Experimental Botany 63: 147-157.

[19] Ebrahimi, M., Miri Karbasak, E., (2016): Investigation effect of humic acid on germination, seedling growth and photosynthesis pigments of medicinal plant Isabgol (Plantago ovata Forssk). - Iranian Journal of Seed Science and Research 3(3): 35-46 (in Persian).

[20] El-Sherbeny, S. E., Hendawy, S. F., Youssef, A. A., Naguib, N. Y., Hussein, M. S. (2012): Response of turnip (Brassica rapa) plants to minerals or organic fertilizers treatments. - Journal of Applied Sciences Research 8(2): 628-634.

[21] Fahad, S., Hussain, S., Matloob, A., Khan, F. A., Khaliq, A., Saud, et al. (2015): Phytohormones and plant responses to salinity stress: a review. - Plant Growth Regulation 75(2): 391-404.

[22] FAO (1972): Soil Institute and Associated Pilot Development Project: Water Management and Soil Reclamation. - Technical Report 3. FAO, Rome.

[23] Gulser, F., Sonmez, F., Boysan, S. (2010): Effects of calcium nitrate and humic acid on pepper seedling growth under saline condition. - Journal of Environmental Biology 31(5): 873-876.

[24] Hadian, J., Azizi, A., Tabatabaei, M. F., Naghavi, M. R., Jamzad, Z., Friedt, W. (2010): Analysis of the genetic diversity and affinities of different Iranian SaturejaSpecies based on SAMPL markers. - Planta Medica (Journal of Medicinal Plant and Natural Product Research) 76: 1927-1933.

[25] Jamil, M., Lee, C. C., Rehman, S. U., Lee, D. B., Ashraf, M., Rha, E. S. (2005): Salinity $(\mathrm{NaCl})$ tolerance of Brassica species at germination and early seedling growth. - Journal of Environ. Agric. Food Chem 4: 970-976.

[26] Jamzad, Z. (2009): Iranian Thyme and Satureja. - Research Institute of Forests and Rangelands of Iran, Tehran, pp. 171-172.

[27] Jariene, E., Danilcenko, H., Kulaitiene, J., Gajewski, M. (2007): Effect of fertilizers on oil pumpkin seeds crude fat, fibre and protein quality. - Journal of Agronomy Research 5(1): 43-49.

[28] Jouyban, Z. (2012): The effects of salt stress on plant growth. - Technical Journal of Engineering and Applied Sciences 2(1): 7-10.

[29] Jumat, S., Nadia, S., Yousif, E. (2012): Synthesis and characterization of esters derived from ricinoleic acid and evaluation of their low temperature property. - Sains Malaysiana 41: 1239-1244.

[30] Kafi, M., Borzouei, A., Salehi, M., Kamandi, A., Masoumi, A., Nabati, J. (2012): Environmental Stresses Physiology in Plants. - Mashhad Jihad Daneshgahi Publications, Mashhad (in Persian).

[31] Kamkar, A., Tooryan, F., Akhondzadeh Basti, A. (2013): Chemical composition of summer savory (Satureja hortensis L.) essential oil and comparison of antioxidant activity with aqueous and alcoholic extracts. - Iran J Vet Res 68(2): 183-90.

[32] Khalvandi, M., Amerian, M. R, Pirdashti, H.; Baradaran, M., Gholami, A. (2018): Effects of methyl jasmonate on some photosynthetic parameters of peppermint (Mentha piperita) in saline conditions. - Journal of Plant Process and Function 7(23): 233-24 (in Persian).

[33] Khayyat, M., Tafazoli, E., Eshghi, S., Rajaee, S. (2007): Effect of nitrogen, boron, potassium and zinc spary on yield and fruit quality of date palm. - American-Eurasian Journal of Agriculture and Environment Science 2(3): 289-296.

[34] Kochert, G. (1978): Carbohydrate determination by the phenol-sulfuric acid method. Handbook of Phycological Methods 2: 95-97.

[35] Mohebbi, J., Jamzad, Z., Bakhshi Khaniki, G. H. (2016): The conservation status of six endemic Satureja species in Iran. - Journal of Iran Nature 1(1): 74-79. 
[36] Munns, R., James, R. A., Lauchli, A. (2006): Approaches to increasing the salt tolerance of wheat and other cereals. - Journal of Experimental Botany 57: 1025-1043.

[37] Minai, A., Heidari, M. (2013): The impact of drought and humic acid on performance and concentriation of macro elements in the herb boage flowers (Borago officinalis L.). Journal of Plant Production 21(1): 167-182 (in Persian).

[38] Mirza Masoumzadeh, B., Imani, A. A., Khayamaim, S. (2012): Salinity stress effect on proline and chlorophyll rate in four beet cultivars. -Scholars Res. Library 3(12): 54535456.

[39] Mudgal, V., Madaan, N., Mudgal, A., Mishra, S. (2009): Changes in growth and metabolic profile of chickpea under salt stress. - Journal of Applied Biosciences 23: 1436-1446.

[40] Naghizadeh, M., Gholami Shabestari, M., Shamsaddin Saied, M. (2014): The study of some physiological responses of three Iranian saffron (Crocus sativus L.) landraces to salinity stress. - Journal of Saffron Agronomy and Technology 2(2): 127-144.

[41] Najafi, F., Khanvari-Nejad, R. A., Siah Ali, M. (2010): The effect of salt stress on certain physiological parameters in summer savory (Satureja hortensis) plant. - Journal of Stress Physiology and Biochemistry 6: 13-21.

[42] Nakabayashi, R., Saito, K. (2015): Integrated metabolomics for abiotic stress responses in plants. - Current Opinion in Plant Biology 24: 6-10.

[43] Narimani, R., Moghaddam, M., Gasemi Pirbalouti, A., Nemati, S. H. (2018): Effect of humic acid and ascorbate on growth and biochemical traits of Moldavian balm (Dracocephalum moldavica L.) under salinity stress. - Journal of Plant Process and Function 7(23): 297-313 (in Persian).

[44] Nasouti Miandoab, R., Samawat, S., Tehrani, M. M. (2011): The properties of humic acid fertilizer in soil and plant. - Monthly Journal of Agriculture and Food 101: 53-55 (in Persian).

[45] Negrão, S., Schmöckel, S. M., Tester, M. (2017): Evaluating physiological responses of plants to salinity stress. - Annals of Botany 119(1): 1-11.

[46] Noreen, Z., Ashraf, M. (2009): Changes in antioxidant enzymes and some key metabolites in some genetically diverse cultivars of radish (Raphanus sativus L.). Environ. Exp. Bot. 67(2): 395-402.

[47] Nouri, K., Omidi, H., Naghdi badi, H. A., Torabi, H., Fotokian, M. H. (2013): Effects of soil and water salinity on flower yield, soluble compounds, content of saline elements and essential oil quality of German chamomile (Shirazian Babooneh, Matricaria recutita L.). - J. Water Res. Agri. 26(4): 367-379.

[48] Omidbaigi, R., (2004): Production and Processing of Medicinal Plants. - Astan Qods Razavi, Mashhad (in Persian).

[49] Parida, A. K., Das, A. B. (2005): Salt tolerance and salinity effects on plants: a review. Ecotoxicology and Environmental Safety 60(3): 324-349.

[50] Parihar, P., Singh, S., Singh, R., Singh, V. P., Prasad, S. M. (2015): Effect of salinity stress on plants and its tolerance strategies: a review. - Environmental Science and Pollution Research 22(6): 4056-4075.

[51] Parvaiz, A., Satyawati, S. (2008): Salt stress and phyto-biochemical responses of plantsa review. - Plant, Soil and Environment 54: 88-99.

[52] Parvin, S., Lee, O. R., Sathiyaraj, G., Khoralragchaa, A., Kim, Y. J., Miah, M. J., Yang, D. C., (2012): Modulation of polyamine levels in ginseng hairy root cultures subjected to salt stress. - Russian Journal of Plant Physiology 59(6): 757-765.

[53] Salimi, F.; Shekari, F., Hamzei, J. (2014): Effect of salinity stress and foliar application of methyl jasmonate on photosynthetic rate, stomatal conductance, water use efficiency and yield of German chamomile. - Iranian Journal of Field Crops Research 12(2): 328334 (in Persian).

[54] Sabouri, F., Sirousmehr, A., Gorgini Shabankareh, H. (2017): Effect of irrigation regimes and application of humic acid on some morphological and physiological characteristics of 
Savory (Satureja hortensis L.). - Iranian Journal of Plant Biology 9(34): 13-24 (in Persian).

[55] Seckin, B., Turkan, I., Sekmen, A. H., Ozfidan, C. (2010): The role of antioxidant defence systems at differential salt tolerance of Hordeum marinum Huds. (sea barleygrass) and Hordeum vulgare L. (cultivated barley). - Environmental and Experimental Botany 69: 76-85.

[56] Setia, R., Gottschalk, P., Smith, P., Marschner, P., Baldock, J., Setia, D., Smith, J. (2013): Soil salinity decreases global soil organic carbon stocks. - Science of the Total Environment 465: 267-272.

[57] Soltani, A., Galeshi, S. (2002): Importance of rapid canopy closure for wheat production in a temperate sub-humidenvironment: experimentation and simulation. - Field Crops Research 77: 17-30.

[58] Rajaravindran, M., Natarajan, S. (2012): Effectsof salinity stress on growth and antioxidantenzymes of the halophyte Sesuvium portulacastrum. - International Journal of Research in Plant Science; 2(1): 23-28.

[59] Razavizadeh, R., Rostami, F. (2013): Changes in growth and antioxidant capacity of canola by salinity and salicylic acid under in vitro. - International Research Journal of Applied and Basic Sciences 5(2): 192-200.

[60] Ritchie, S. W., Nguyen, H. T. (1990): Leaf water content and gas exchange parameters of two wheat genotypes differing in drought resistance. - Crop Science 30: 105-111.

[61] Saleh, B. (2013): Water status and protein pattern changes towards salt stress in cotton. Journal of Stress Physiology \& Biochemistry 9(1): 113-123.

[62] Salimon, J., Salih, N., Yousif, E. (2012): Biolubricant basestocks from chemically modified ricinoleic acid. - Journal of King Saudi University 24: 11-17.

[63] Saruhan, V., Kusvuran, A., Babat, S. (2011): The effect of different humic acid fertilization on yield and yield components performances of common millet (Panicum miliaceum L.). - Scientific Research and Essays 6(3): 663-669.

[64] Sevengor, S., Yasar, F., Kusvuran, S., Ellialtioglu, S. (2011): The effect of salt stress on growth, chlorophyll content, lipid peroxidation and antioxidative enzymes of pumpkin seedling. - African Journal of Agricultural Research 6(21): 4920-4924.

[65] Shaaban, S. H. A., Manal, F. M., Afifi, M. H. M. (2009): Humic acid foliarb application to minimize soil applied fertilization of surface- irrigated Wheat. - Worlds Journal of Agriculture Science 5(2): 207-210.

[66] Shariff, M. (2002): Effect of lignitic coal derived HA on growth and yield of wheat and maize in alkaline soil. - Ph. D Dissertation, NWFP Agriculture University Peshawar, Pakistan.

[67] Sinclair, I. R., Ludlow, M. M. (1985): Who taught plants thermodynamics? The unfulfilled potential of plant water potential. - Aus. J. Plantphysiol. 12: 213-217.

[68] Sivritepe, N., Sivritepe, O., Celik, H., Katkat, V. (2010): Salinity responses of grafted grapevines: effects of scion and rootstock genotypes. - Not. Bot. Hort. Agrobot. Cluj. 38(3): 193-201.

[69] Slama, I., Ghnaya, T., Hessini, K., Messedi, D., Savoure, A., Abdelly, C. (2007): Comparative study of the effects of mannitol and PEG osmotic stress on growth and solute accumulation in Sesuvium portulacastrum. - Environmental and Experimental Botany 61: 10-17.

[70] Sudhakar, P., Latha, P., Reddy, P. V. (2016): Phenotyping Crop Plants for Physiological and Biochemical Traits. - Academic Press, Cambridge, MA.

[71] Sudhir, P., Murthy, S. D. S. (2004): Effects of salt stress on basic processes of photosynthesis. - Photosynthetica 42: 481-486.

[72] Vafadar, Z., Rahimmalek, M., Sabzalian, M. R., Nikbakht, A. (2018): Effect of salt stress and harvesting time on morphological and physiological characteristics of Myrtle (Myrthus communis). - Journal of Plant Process and Function 7(23): 33-47 (in Persian). 
[73] Vojodi Mehrabani, L., Hassanpour Aghdam, M. B., Valizadeh Kamran, R. (2017): Growth and some physiological characteristics of savory (Satureja hortensis L.) as affected by salinity stress. - Journal of Crop Ecophysiology 11(1): 99-110 (in Persian).

[74] Zhani, K., Mariem, B. F., Fardaous, M., Cherif, H. (2012): Impact of Salt stress (NaCl) on growth, chlorophyll content and fluorescence of Tunisian cultivars of chilli pepper (Capsicum frutescens L.). - Journal of Stress Physiology \&Biochemistry 8(4): 236-252. 